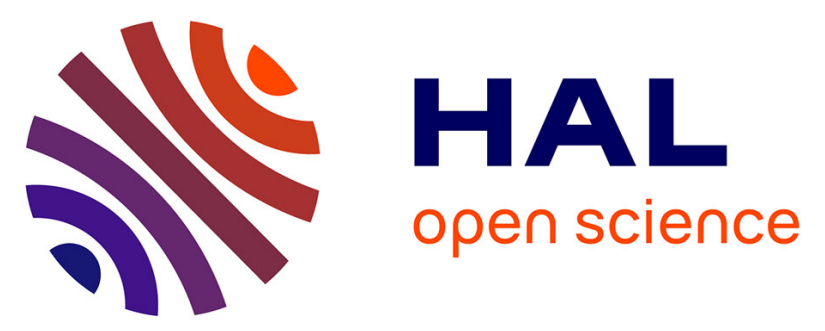

\title{
Spatial distribution and habitat characterization of marine animal forest assemblages along nine submarine canyons of Eastern Sardinia (central Mediterranean Sea)
}

\author{
Davide Moccia, Alessandro Cau, Lorenzo Bramanti, Laura Carugati, \\ Simonepietro Canese, Maria Cristina Follesa, Rita Cannas
}

\section{To cite this version:}

Davide Moccia, Alessandro Cau, Lorenzo Bramanti, Laura Carugati, Simonepietro Canese, et al.. Spatial distribution and habitat characterization of marine animal forest assemblages along nine submarine canyons of Eastern Sardinia (central Mediterranean Sea). Deep Sea Research Part I: Oceanographic Research Papers, 2020, pp.103422. 10.1016/j.dsr.2020.103422 . hal-02987605

\section{HAL Id: hal-02987605 https://hal.science/hal-02987605}

Submitted on 24 Nov 2020

HAL is a multi-disciplinary open access archive for the deposit and dissemination of scientific research documents, whether they are published or not. The documents may come from teaching and research institutions in France or abroad, or from public or private research centers.
L'archive ouverte pluridisciplinaire HAL, est destinée au dépôt et à la diffusion de documents scientifiques de niveau recherche, publiés ou non, émanant des établissements d'enseignement et de recherche français ou étrangers, des laboratoires publics ou privés. 


\title{
Spatial distribution and habitat characterization of marine animal forest assemblages along nine submarine canyons of Eastern Sardinia (central Mediterranean Sea)
}

\author{
Davide Moccia $^{\mathrm{a}, *}$, Alessandro Cau ${ }^{\mathrm{a}}$, Lorenzo Bramanti ${ }^{\mathrm{b}}$, Laura Carugati ${ }^{\mathrm{a}}$, Simonepietro Canese $^{\mathrm{c}}$, \\ Maria Cristina Follesa ${ }^{a}$, Rita Cannas ${ }^{a}$ \\ a Dipartimento Delle Scienze Della Vita e Dell'ambiente, Università di Cagliari, Cagliari, Italy

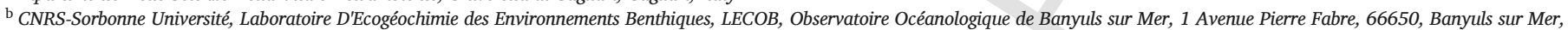 \\ France \\ c Stazione Zoologica Anton Dohrn, Villa Comunale, Napoli, 80121, Italy
}

\section{A R T I C LE IN F O}

\section{Keywords}

Vulnerable marine ecosystems

Coral assemblages

Seafloor characteristics

ROV imaging

Twilight zone

Marine litter

\begin{abstract}
A B S T R A C T
Submarine canyons are peculiar habitats of the continental margin due to their hydrodynamic and geomorphological features. Coral assemblages forming marine animal forests (MAFs) are one of the key benthic components dwelling in these habitats, where they enhance the substrate's heterogeneity and provide shelter, feeding and spawning habitats for a wide variety of species. They are also considered Vulnerable Marine Ecosystems (VMEs), since their fragile three-dimensional framework and slow growth rate exposes them to multiple anthropogenic stressors. Understanding the coupling processes between environmental factors and the scale at which coral assemblages develop in these habitats, is an essential step towards their protection. This study aims to identify MAFs along submarine canyons in the central Mediterranean basin (Eastern Sardinia) on the basis of video transects carried out using Remotely Operated Vehicle and test the influence of environmental variables (silt coverage, distance from the coast, water depth and slope of the substrate) in driving the spatial distribution variability. We identified nine MAF assemblages dwelling in both rocky and silted substrate, from 90 to $220 \mathrm{~m}$ depth. We found that the most significant variability in densities and diversity of MAF assemblages occurs mostly within canyons rather than among canyons that are distant hundreds of $\mathrm{km}$ apart. Distance-based linear modelling (DistLM) identified silt coverage and water depth as the main factors explaining the observed variability. Overall our study provided new insights on MAFs composition and spatial distribution in submarine canyons which are, in turn, strongly influenced by local physical conditions. Such results emphasized the need for sound in situ conservation strategies in order to preserve MAFs and their ecological role.
\end{abstract}

\section{Introduction}

Submarine canyons are outstanding features of continental margins that contribute to the channeling of water masses, sediments and organic matter from shores to deep-sea basins (Weaver et al., 2004; Canals et al., 2006). Their geomorphology affects water flow, generating fast currents, turbulence and sediment resuspension, thus creating organic enriched environments (De Leo et al., 2010; Pusceddu et al., 2010; Duffy et al., 2014). These processes contribute to increase both pelagic and benthic productivity as well as biomass, abundance and biodiversity of benthic fauna (Vetter, 1994; Fabri et al., 2014; D'Onghia et al., 2015; Lastras et al., 2016; Fernández-Arcaya et al., 2017). Some canyons are indeed considered biodiversity "hotspots" (Schlacher et al., 2007; Levin et al., 2010; Carugati et al., 2019), and preferential recruitment areas (Sardà et al., 2004).

Distribution and diversity patterns of the biota living in submarine canyons are influenced by a complex array of factors, including seafloor heterogeneity, hydrographic conditions, C inputs, food availability, and disturbance events (Okey, 2003; McClain and Barry, 2010; De Leo et al., 2014; Grinyó et al., 2018; Campanyà-Llovet et al., 2018). These factors are, in turn, related to several peculiar physical characteristics (i.e. proximity to river systems, substrate lithology, sediment transport processes, sedimentation rates, nutrient input and water depth; Harris and Whiteway, 2011). Therefore, different canyons or even diverse sections of a single canyon may be substantially different (De Leo et al., 2014; Puig et al., 2014). Such differences result into a high degree of physical and biological variability at both the intra- and inter-canyon

\footnotetext{
* Corresponding author.

E-mail address: mocciadavide@unica.it (D. Moccia)
} 
level (McClain and Barry, 2010; Wü rtz, 2012), so that understanding factors driving community composition can be very challenging.

Recent advances in technology such as Remotely Operated Vehicles (ROVs), swath bathymetry and side-scan sonar have allowed to better understand geomorphological features, processes and biodiversity through a non-invasive procedure based on underwater footage (Fernández-Arcaya et al., 2017; Canals et al., 2019; Chimienti et al., 2019a,b; Fabri et al., 2019). However, knowledge of the benthic communities' species richness, composition, and factors regulating their variability at different spatial scales is still scant.

Due to its geographical location and geomorphology, the island of Sardinia represents an interesting area within the Mediterranean' scenario to study submarine canyons processes and the associated biodiversity. The southern and western coasts are characterized by a wide continental shelf with a gradual decline that ends at $200 \mathrm{~m}$ depth, while the eastern coast is characterized by a narrow continental shelf that mostly terminate at about $60-100 \mathrm{~m}$ depth (Ulzega and Fais, 1980; Lecca., 2000). This narrow continental shelf is incised by a complex submarine canyons system, few miles from the coastline, that locally alter water circulation, canalize organic matter particles, and provide different physical substrates that significantly contribute to enance marine biodiversity (Harris and Whiteway, 2011; Würtz et al., 2012). This particular conditions lead to the develop of numerous and diversificated deep-sea habitat-forming assemblages, from the shallow depths of the continenatls shelf down to the bathial plan, in areas close to the coastline and, in turn, easy to reach.

Benthic suspension feeders represent one of the numerous components of the marine biota that can be influenced by submarine canyons features (Fabri et al., 2017; Pierdomenico et al., 2019). Benthic communities dominated by large arborescent anthozoans and other suspension feeders create important three-dimensional structures described as 'marine animal forests' (MAFs), that morphologically and ecologically resemble their terrestrial counterpart (Rossi et al., 2017; Cau et al., 2017c). MAFs play, indeed, a crucial role in the benthic-pelagic coupling processes (Buhl-Mortensen et al., 2010), organic matter accumulation (Cerrano et al., 2015) providing also shelter, feeding, reproductive or spawning areas for a rich associated fauna (D'Onghia et al., 2010; Gori et al., 2011, 2017; Cau et al., 2017b; Chimienti, 2020a, 2020b). These habitat-forming assemblages are known to occur from the continental shelf and shelf break, where they can constitute an important part of the mesophotic ecosystems of the twilight zone (Rossi et al., 2012; Rossi, 2013), down to the canyon's walls and thalwegs, where they contribute to the deep-sea communities (De Leo et al., 2010). MAFs can be constiuted by species with different geographical and depth ranges, from the shallow gorgonians Eunicella cavolinii (Koch, 1887) and Paramuricea clavata (Risso 1826), that mostly occur at 50-60 m depth, to deeper scleractinians Dendrophyllia cornigera (Lamarck, 1816) and Madrepora oculata (Linnaeus, 1758), that mostly occur at depth $>200 \mathrm{~m}$ (Altuna and Poliseno, 2019).

Because of their demography (Bramanti et al., 2019; Girard et al., 2019) and tridimensional structure, these animal forests are particularly vulnerable to mechanical injuries inflicted by anthropogenic pressures, such as direct fishing activities (bottom trawling, longlines and trammel nets) and their indirect consequences (Derelict Fishing Gears - DFGs, sediment resuspension and consequently silting), as well as the accumulation of marine litter (Puig et al., 2012; Clark et al., 2016; D'Onghia et al., 2017; Hinz, 2017; Giusti et al., 2019; Gori et al., 2019; Puig and Gili, 2019). Beside fishing activities, other aspects are further impacting
MAFs assemblages worldwide, including climate-change driven events (i.e. warming and ocean acidification) (McCulloch et al., 2010; Roberts and Cairns 2014; Gori et al., 2017; Ragnarsson et al., 2017), chemical pollution (terrestrial nutrient loads, disposal of solid waste from mines and oil spills) (Montagna et al., 2006; Fabri et al., 2014; Otero et al., 2016), and seafloor drilling activities (Aguilar 2004; Larsson et al., 2013). The consequences of these pressures on MAFs have been extensively documented (Cau et al., 2017a; Gori et al., 2017; Ragnarsson et al., 2017; Galgani et al., 2018). In a highly anthropized and overexploited basin such as the Mediterranean Sea (Bianchi et al., 2012), a reduction of MAFs abundance or a shift in their distribution is further expected (Bo et al., 2015).

Since 2006 the United Nations General Assembly (Resolution A/ $\mathrm{RES} / 61 / 105)$ has included MAFs forming species and communities (i.e. Octocorallia, Anthipatharia and Scleractinian) among the group of species that contribute to forming vulnerable marine ecosystems (VMEs) with a mandate to FAO to manage deep-sea fisheries and to adopt measures that reduce or eliminate the impact of bottom fishing gears on VMEs (FAO, 2016). On a broader sense, according to the FAO International Guidelines for the Management of Deep-sea Fisheries in the High Seas (FAO, 2009), VMEs includes not only groups of species with certain life-history traits (e.g., maturation at relatively old age, slow growth rates, long life expectancies, low or unpredictable recruitment), but also habitats that may be vulnerable to impacts from fishing activities. In Annex 1 of the FAO Deep-sea Fisheries Guidelines, submarine canyons and coral-dominated communities are included in the "VMEs indicator features" and "VME indicator habitats", respectively (FAO, 2016).

Concerning the Mediterranean Sea, the General Fisheries Commission for the Mediterranean (GFCM) has recently defined Mediterranean VME indicators (features, habitas and taxa) within its management regulations (GFCM, 2017; 2018). GFMC has also established Fisheries Restricted Areas (hereafter FRA) as a multi-purpose spatial-management tool to restrict fishing activities and protect sensitive deep-sea habitats, such as VMEs, and essential fish habitats (FAO, 2016). Apart from Recommendation GFCM/29/2005/118 that prohibits the use of towed dredges and trawl nets at depths greater than $1000 \mathrm{~m}$, three FRAs have been established in Mediterranean international waters, in which fishing activities with towed dredges and bottom trawl nets are permanently prohibited with the aim of protecting vulnerable deep-sea habitats; these include a cold hydrocarbon seeps in Egypt, a seamount off Cyprus, and a cold-water coral Lophelia reef in the Italian Ionian Sea (Recommendation GFCM/30/2006/3). However, GFCM is asked to prevent further significant adverse impacts on VMEs with the establishment of new FRAs, for which extensive information is required related to the area, site description, biological features, human activities and impacts. Within this framework, implementing knowledge on areas where VMEs indicators features (submarine canyons) and VMEs indicators habitat (MAFs assemblages) are concentrated represent important informations needed to support the creation of new FRAs and to preserve VMEs.

The present study aims at investigating MAFs assemblages dwelling in nine canyons along the eastern Sardinia continental margin (Central-Western Mediterranean). The main goal is to describe the biodiversity of coral assemblages (in terms of species richness and composition) and explore the role of environmental factors (silt coverage, distance from the coast, water depth, slope of the substrate) in influencing their spatial distribution. Furthermore, we document the presence of different categories of seafloor litter observed in MFAs' habitats. 


\section{Materials and methods}

\subsection{Study area}

The study area covers the shelf break of the eastern Sardinian continental margin which represents the passive margin of the Tyrrhenian basin, delimited to the north by the Etruschi seamount and to the south by the Ichnusa Seamount (Fig. 1). The eastern sea bottoms are characterized by a narrow continental shelf that terminates at about $60-100 \mathrm{~m}$ depth in the southern and central areas, while around $200 \mathrm{~m}$ depth in the northern area. In the eastern Sardinian coast the continental shelf and the slope are connected to the peculiar inland orographic structure and river basin: narrow inlets, separated by high and steep mountains, are connected through a very narrow continental shelf with irregular bottoms to the slope incised by profound canyons (Sulli, 2000; Mascle et al., 2001; Harris and Whiteway, 2011).

\subsection{ROV surveys}

Within the study area, we selected and investigated nine canyons which were a priori allocated to three geographical areas: namely North-east including Caprera, Mortorio and Tavolara, (hereafter NC, NM and NT), Central-east including Orosei, Gonone and Arbatax (hereafter CO, CG, CA) and South-east including S. Lorenzo, Picocca, and Simius Canyons (hereafter SL, SP, SS) (Fig. 1; Table 1).
The three northern canyons incise a considerable width portion of the northern continental shelf (around $20 \mathrm{~km}$ ); they are located respectively at ca. 9.2, 7.5 and 7.2 nautical miles from the nearest coast. On each of the three canyons (NC, NM and NT) three ROV dives were carried out, while seven ROV dives were carried out in the central part of the Sardinia margin (three in CO, two in CG and two in CA) to investigate the Orosei-Gonone canyon system, characterized by the absence of large rivers, and the narrow Arbatax canyon right in front of the flow of river Pramaera. CO is the central farthest canyon from the coast as it is located at 6.1 nautical miles from the Orosei bay, while CG and CA are respectively 0.4 and 1.9 nautical miles distant from the nearest coast. In the southern group, seven ROV dives were performed over the S. Lorenzo, Picocca and Simius canyons (two in SL, three in SP and two in SS). Their distance from the coast varied from the closest SL and SS canyons located at ca. 1.1 and 1.4 nautical miles respectively, to the farthest SP canyon located at ca 4.6 nautical miles from the nearest coastline.

\subsection{Video processing}

The dataset used in this study includes video and photographs collected along the eastern Sardinia continental margin during two ROV surveys conducted in October 2011 and August 2013 on board of the R/V "Astrea". ROV campaigns were funded by the department Environmental and Life Science of the University of Cagliari, with the main focus on the investigation of the status of Corallium rubrum populations. The Remote Operated Vehicle "Pollux III" was used in

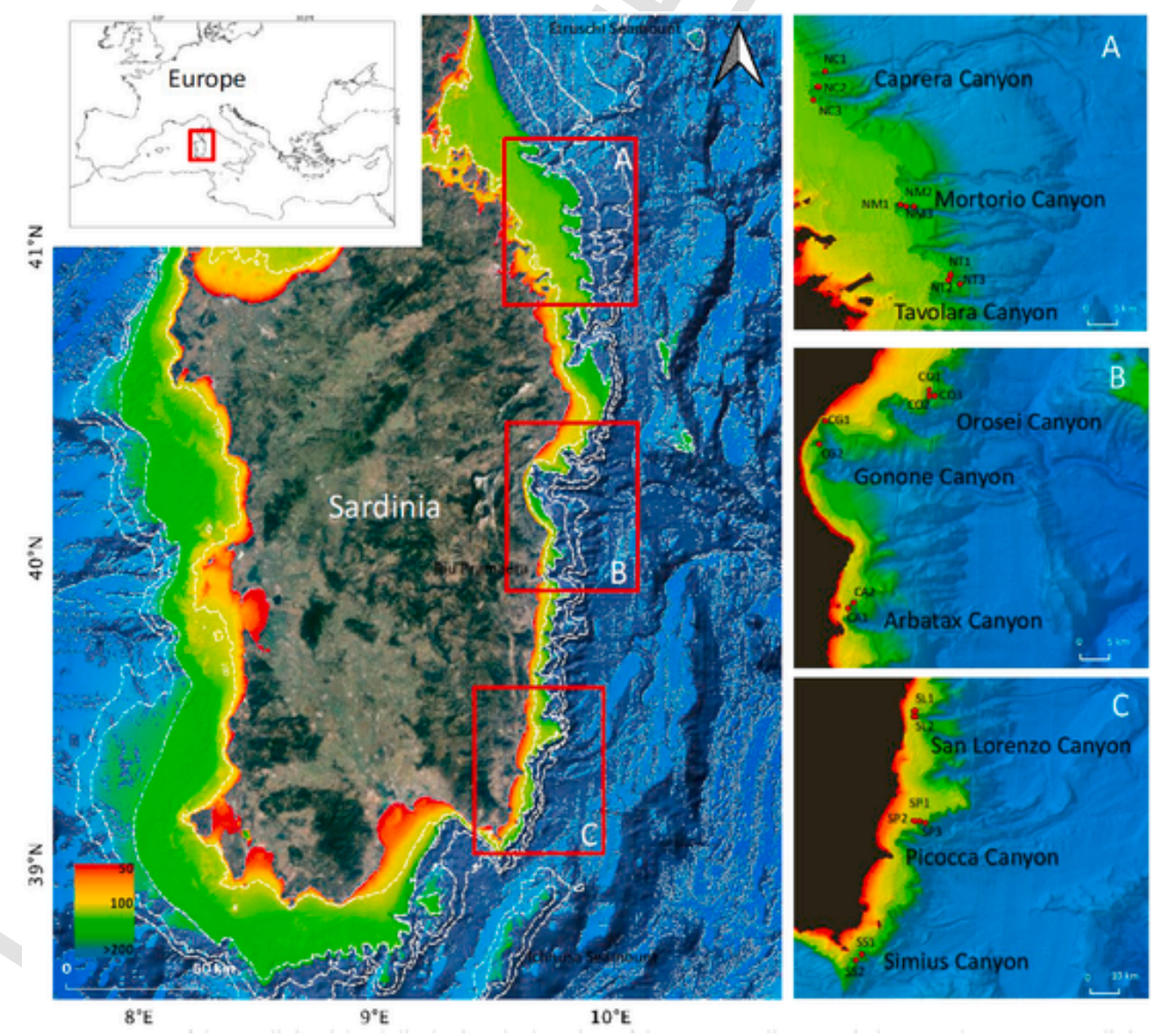

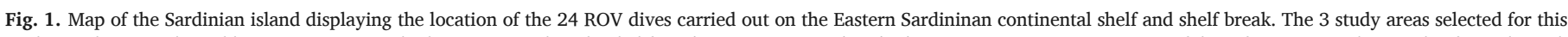

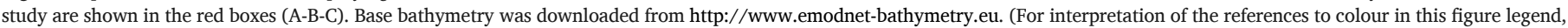
the reader is referred to the Web version of this article.) 
Table 1

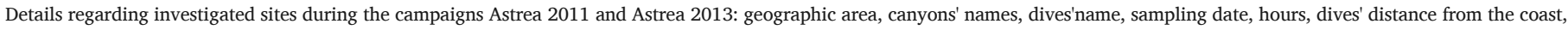
depth range and coordinates.

\begin{tabular}{|c|c|c|c|c|c|c|c|c|}
\hline Geographic area & Canyon & Dive name & Date & Hours & Distance from the coast (Nm) & Depth range (m) & Coordinates & \\
\hline & & & & & & & Lat $(\mathrm{N})$ & Long (E) \\
\hline North-east & Caprera Canyon & NC1 & $27 / 08 / 2013$ & 01:55 & 12.1 & $121-150$ & $41^{\circ} 20^{\prime} 26.0^{\prime \prime}$ & $9^{\circ} 38^{\prime} 07.3^{\prime \prime}$ \\
\hline North-east & Caprera Canyon & NC2 & $24 / 08 / 2013$ & $01: 45$ & 10.3 & $127-187$ & $41^{\circ} 18^{\prime} 21.4^{\prime \prime}$ & $9^{\circ} 38^{\prime} 01.3^{\prime \prime}$ \\
\hline North-east & Caprera Canyon & NC3 & $26 / 08 / 2013$ & $02: 42$ & 9.0 & $110-220$ & $41^{\circ} 17^{\prime} 25.6^{\prime \prime}$ & $9^{\circ} 37^{\prime} 28.9^{\prime \prime}$ \\
\hline North-east & Mortorio Canyon & NM1 & $26 / 08 / 2013$ & $01: 44$ & 7.4 & $100-120$ & $41^{\circ} 04^{\prime} 13.0^{\prime \prime}$ & $9^{\circ} 47^{\prime} 53.9^{\prime \prime}$ \\
\hline North-east & Mortorio Canyon & NM2 & $26 / 08 / 2013$ & $01: 47$ & 7.5 & $112-145$ & $41^{\circ} 04^{\prime} 09.1^{\prime \prime}$ & $9^{\circ} 47^{\prime} 50.7^{\prime \prime}$ \\
\hline North-east & Mortorio Canyon & NM3 & $26 / 08 / 2013$ & $01: 25$ & 7.8 & $126-140$ & $41^{\circ} 04^{\prime} 12.0^{\prime \prime}$ & $9^{\circ} 48^{\prime} 13.4^{\prime \prime}$ \\
\hline North-east & Tavolara Canyon & NT1 & $23 / 08 / 2013$ & 03:16 & 9.9 & $105-198$ & $40^{\circ} 55^{\prime} 10.1^{\prime \prime}$ & $9^{\circ} 54^{\prime} 08.4^{\prime \prime}$ \\
\hline North-east & Tavolara Canyon & NT2 & $29 / 08 / 2013$ & 01:37 & 8.5 & $107-170$ & $40^{\circ} 544^{\prime} 51.6^{\prime \prime}$ & $9^{\circ} 54^{\prime} 02.5^{\prime \prime}$ \\
\hline North-east & Tavolara Canyon & NT3 & $29 / 08 / 2013$ & 02:20 & 9.4 & $126-290$ & $40^{\circ} 544^{\prime} 46.1^{\prime \prime}$ & $9^{\circ} 54^{\prime} 54.5^{\prime \prime}$ \\
\hline Central-east & Orosei Canyon & $\mathrm{CO} 1$ & $20 / 08 / 2013$ & 01:55 & 6.1 & $93-120$ & $40^{\circ} 21^{\prime} 49.5^{\prime \prime}$ & $9^{\circ} 53^{\prime} 40.2^{\prime \prime}$ \\
\hline Central-east & Orosei Canyon & $\mathrm{CO} 2$ & $22 / 08 / 2013$ & $00: 44$ & 6.1 & $98-120$ & $40^{\circ} 21^{\prime} 46.0^{\prime \prime}$ & $9^{\circ} 53^{\prime} 39.4^{\prime \prime}$ \\
\hline Central-east & Orosei Canyon & $\mathrm{CO} 3$ & $22 / 08 / 2013$ & $01: 25$ & 6.3 & $156-186$ & $40^{\circ} 21^{\prime} 41.5^{\prime \prime}$ & $9^{\circ} 53^{\prime} 57.0^{\prime \prime}$ \\
\hline Central-east & Cala Gonone Canyon & CG1 & $19 / 08 / 2013$ & $01: 29$ & 0.4 & $90-120$ & $40^{\circ} 18^{\prime} 54.7^{\prime \prime}$ & $9^{\circ} 40^{\prime} 27.9^{\prime \prime}$ \\
\hline Central-east & Cala Gonone Canyon & CG2 & $30 /{ }^{\prime} 08 / 2013$ & 02:00 & 0.9 & $98-120$ & $40^{\circ} 17^{\prime} 32.6^{\prime \prime}$ & $9^{\circ} 40^{\prime} 15.1^{\prime \prime}$ \\
\hline Central-east & Arbatax Canyon & CA1 & $31 / 08 / 2013$ & $00: 45$ & 1.9 & $108-147$ & $39^{\circ} 58^{\prime} 08.2^{\prime \prime}$ & $9^{\circ} 43^{\prime} 44.0^{\prime \prime}$ \\
\hline Central-east & Arbatax Canyon & CA2 & $31 / 08 / 2013$ & $01: 25$ & 1.9 & $121-180$ & $39^{\circ} 58^{\prime} 46.8^{\prime \prime}$ & $9^{\circ} 43^{\prime} 45.6^{\prime \prime}$ \\
\hline South-east & San Lorenzo Canyon & SL1 & $13 / 10 / 2011$ & $01: 27$ & 1.2 & $95-130$ & $39^{\circ} 37^{\prime} 25.7^{\prime \prime}$ & $9^{\circ} 40^{\prime} 51.9^{\prime \prime}$ \\
\hline South-east & San Lorenzo Canyon & SL2 & $13 / 10 / 2011$ & $02: 41$ & 1.2 & 99-145 & $39^{\circ} 37^{\prime} 22.0^{\prime \prime}$ & $9^{\circ} 40^{\prime} 51.4^{\prime \prime}$ \\
\hline South-east & Picocca Canyon & SP1 & $10 / 11 / 2011$ & 02:17 & 4.5 & $124-280$ & $39^{\circ} 22^{\prime} 45.7^{\prime \prime}$ & $9^{\circ} 42^{\prime} 29.0^{\prime \prime}$ \\
\hline South-east & Picocca Canyon & SP2 & $10 / 11 / 2011$ & 02:05 & 3.7 & $115-140$ & $39^{\circ} 22^{\prime} 72.0^{\prime \prime}$ & $9^{\circ} 41^{\prime} 17.8^{\prime \prime}$ \\
\hline South-east & Picocca Canyon & SP3 & $10 / 11 / 2011$ & 01:05 & 3.9 & $105-130$ & $39^{\circ} 22^{\prime} 47.0^{\prime \prime}$ & $9^{\circ} 41^{\prime} 35.8^{\prime \prime}$ \\
\hline South-east & Simius Canyon & SS1 & $01 / 09 / 2013$ & $01: 30$ & 2.3 & $120-190$ & $39^{\circ} 03^{\prime} 38.8^{\prime \prime}$ & $9^{\circ} 32^{\prime} 56.8^{\prime \prime}$ \\
\hline South-east & Simius Canyon & SS2 & $01 / 09 / 2013$ & $01: 26$ & 2.0 & $111-170$ & $39^{\circ} 04^{\prime} 46.8^{\prime \prime}$ & $9^{\circ} 33^{\prime} 45.6^{\prime \prime}$ \\
\hline
\end{tabular}

both campaigns; it was equipped with a digital camera (Nikon D80, 10 megapixels), a strobe light (Nikon SB 400), a high definition video camera (Sony HDR-HC7), track-link system, depth sensor, compass, and two parallel laser beams providing a constant 10 -cm reference scale in the video frame, used for the measurement of the area during the image analysis. This non-invasive technology is generally preferred in habitats of high conservation interest as it avoids damages to endangered or protected species.

Overall, we processed a total of $46 \mathrm{~h}$ of ROV footage, collected through 23 transects; transects could not be linear as the surveys were specifically focused on the assessment of the distribution and state of the populations of Corallium rubrum. Before frames extraction, to avoid potential frames' overlap, ROV videos were checked through the analysis of the video sequences and the ROVs tracking path, and the repeated sections were cut off. Still frames were extracted from video every $30 \mathrm{~s}$ using the software DVDVIDEOSOFT. Still frames with a calculated area of $<1 \mathrm{~m}^{2}$ and $>5 \mathrm{~m}^{2}$, as well as those that were not clear or that presented a compromised resolution/focus were discarded in the initial stage of the image analysis.

\subsection{Corals species, seafloor characteristics and human pressure}

In all extrapolated frames all organisms larger than $2 \mathrm{~cm}$ were identified to the lowest taxonomic level, counted and georeferenced. For twelve corals target species, chosen as indicator of MAFs presence along the investigated canyons, densities were calculated: seven gorgonian species [Callogorgia verticillata (Pallas, 1766) (fam. Primnoidae), Paramuricea clavata (Risso 1826) (fam. Plexauridae), Corallium rubrum (Linnaeus, 1758) (fam. Coralliidae), Viminella flagellum (Johnson, 1863) (fam. Ellisellidae), Acanthogorgia hirsuta (Gray, 1857) (fam. Acanthogorgiidae), Eunicella cavolinii (Koch, 1887) (fam. Gorgoniidae), Bebryce mollis (Philippi, 1842) (fam. Plexauridae)], four antipatharians [Antipathella subpinnata (Ellis and Solander, 1786) (fam. Myriopathidae), Antipathes dichotoma (Pallas, 1766) (fam. Antiphatidae), Parantipathes larix (Esper, 1790) (fam. Schizopathidae) and Leiopathes glaberrima (Esper, 1788) (fam. Leiopathidae)], and one scleractinian Dendrophylla cornigera (Lamarck, 1816) (fam. Dendrophylliidae). Even though the selected anthozoan species represent a portion of the complex hard-bottom community inhabiting the investigated rocky canyons, they were chosen as the target of this study because their presence is either supportive of high levels of megabenthic biodiversity and, depending on their longevity, also indicative of stable assemblages (Bo et al., 2015). All the selected species are long-lived organisms that can potentially form outstanding colonies in terms of size (i.e., maximum height) and/or branching patterns. Their arborescent or three-dimensionally developed shape can, indeed, potentially influence major currents' flows retaining particles, zooplankton, eggs, larvae, juveniles and adults of vagile species (Baillon et al., 2012; Rossi, 2013). Image analysis was performed with the CPCe software (Kohler and Gill, 2006) to obtain the target coral densities, expressed as the number of colonies $\mathrm{m}^{2} \pm$ standard error; hereafter col $\mathrm{m}^{2} \pm$ S.E. When no corals were registered in the analyzed frames, coral density was equal to zero.

Quantum GIS Desktop (QGIS Development Team, 2016, version 3.4.11-Madeira) software was used to geo-refence ROV dives and coral species, and to create coral assemblages composition and densities maps.

The bathymetrical distribution of the coral species was recorded directly through the whole footage during the video sampling. At the same time, slope and silt cover of the substrate were estimated a posteriori during the image analysis process. Substrate slope was estimated using a scale from 0 to 4 where 1 is flat $\left(0^{\circ}-10^{\circ}\right), 2$ is inclined $\left(10^{\circ}-45^{\circ}\right), 3$ is vertical $\left(45-90^{\circ}\right)$ and 4 is overhang $\left(>90^{\circ}\right)$. Silt coverage was classified using a scale from 1 to 3 , referring to 3 categories (category 1 or low silted $=0-10 \%$ silt coverage, category 2 or medium-silted $=10-50 \%$ silt coverage, category 3 or high-silted = 
$>50 \%$ silt coverage). All the seafloor characteristics were estimated for all the frames anlysed.

The level of anthropic pressure, in terms of number of items $/ \mathrm{m}^{2}$, was extrapolated from Cau et al. (2018). In this study, the dataset was divided into 6 mains categories: (1) disposal plastic items; 2) fishing nets; 3) fishing ropes; 4) fishing longlines; 5) metal items; 6) glass items.

\subsection{Statistical analyses}

The identification of different coral assemblages was made through the use of hierarchical cluster analysis with group-averaged linkage, using a Bray-Curtis similarity matrix derived from square root transformed data of target species densities. The similarity profile test (SIMPROF) was applied to determine if significant differences occur between different clusters, while the similarity percentages (SIMPER) routine was used to identify the key species characterizing those clusters. After the corals assemblages were identified, the seafloor characteristics, depth, distance from the coast, target coral denisties and marine litter associated to each assemblage were extrapolated and used for the creation of geo-refentiated maps, tables and the furher statistical analyses.

The non-normal distribution of the dataset was verified through the software XLSTAT (function 'normality test'; P $<0.0001$ ). Differences in coral assemblages' density $\left(\mathrm{col} / \mathrm{m}^{2}\right)$ (uni-variate) and coral assemblages' composition (multi-variate) among and within different geographic areas were tested through a PERmutational Analysis of Variance (PERMANOVA; Anderson, 2001). The experimental design included two factors, with a nested design, as unique source of variation. The first factor was 'Area', with three fixed levels: North, Central and South; the second factor was 'Canyon' (with three random levels nested in 'Area'). PERMANOVA was based on Bray-Curtis distances matrix of previously square-roots data (Anderson, 2001). Since the PERMANOVA showed significant variations in the composition of coral assemblages within sampling units belonging to same canyons, but not to same areas, the three areas were analyzed separately. A similarity percentage analysis (SIMPER) was employed to reveal which assemblage contributed the most to the dissimilarity within and among canyons per area. Due to the large difference in the abundance between species, SIMPER analyses were carried out based on the square root transformed abundance data with $90 \%$ cut-off.

To test the influence of seafloor characteristics (silt coverage, distance from the coast, water depth, slope of the substrate) on coral assemblages' composition, a Distance-based Linear Model (DistLM, Legendre 1999) procedure was performed within each investigated area. DistLM is a regression analysis that models the relationship between a resemblance matrix and a set of environmental variables. Environmental data were normalized, and a stepwise procedure was adopted to test their importance, using Akaike's information criterion (AIC) to rank the resulting model. A distance-based redundancy analysis (dbRDA) was used to visualize the DistLM results. Draftsman plots and correlation matrices computing pairwise scatter-plots comparing covariates were produced to exclude potential multicollinearity of predictor variables. The combinations where any relevant Spearman's Correlation coefficient $(\rho>0.7)$ was observed in pairs were discarded from the analysis.

Multivariate analysis of variance PERMANOVA, DistLM, dbRDA and SIMPER analyses were carried out using routines included in the PRIMER6 + software package (Plymouth Marine Laboratory).

\section{Results}

\subsection{Description, spatial distribution and impacts on corals assemblages}

A total of 1043 frames were used as sampling units for the quantitative analyses of target coral densities, covering an area of ca. 4200 $\mathrm{m}^{2}$. The average area of the analysed frames was $3.7 \mathrm{~m}^{2} \pm 1.9$ S.E. Thirty-seven asscociated species, belonging to six phylum (Porifera, Anellida, Brachiopoda, Crustacea, Echinodermata and Chordata), were identified. The cluster analysis and the SIMPROF test $(\mathrm{P}<0.05)$ identified nine different coral assemblages with a similarity level $>40 \%$ (Fig. 2 ). The spatial distribution of the nine coral assemblages and their mean coral density were plotted within each investigated canyon (Figs. 3 and 4). The environmental descriptors and the density of each target species in the different assemblages are summarized in Table 2, and the list of the associated species recorded within the different assemblages are reported in Table 3 .

\section{Group average}

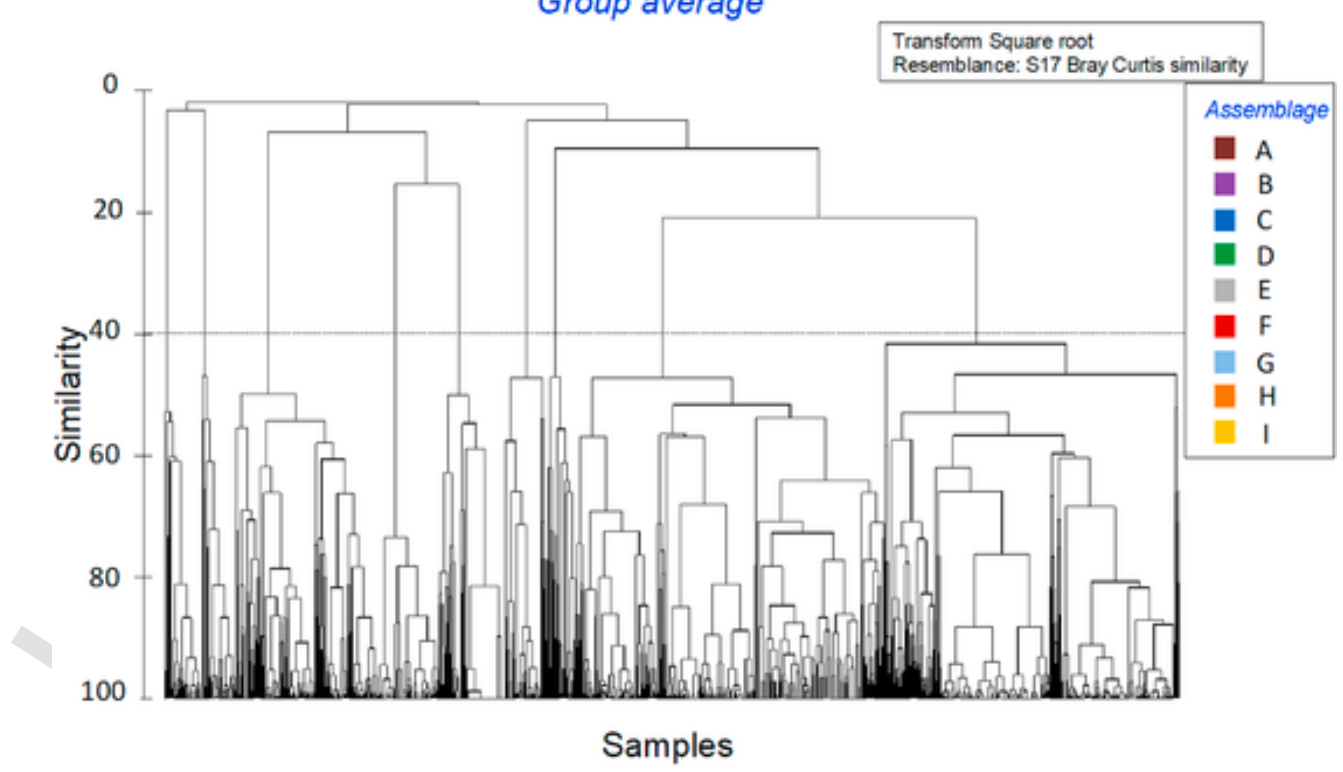

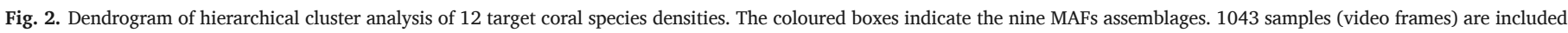
in the analysis. 


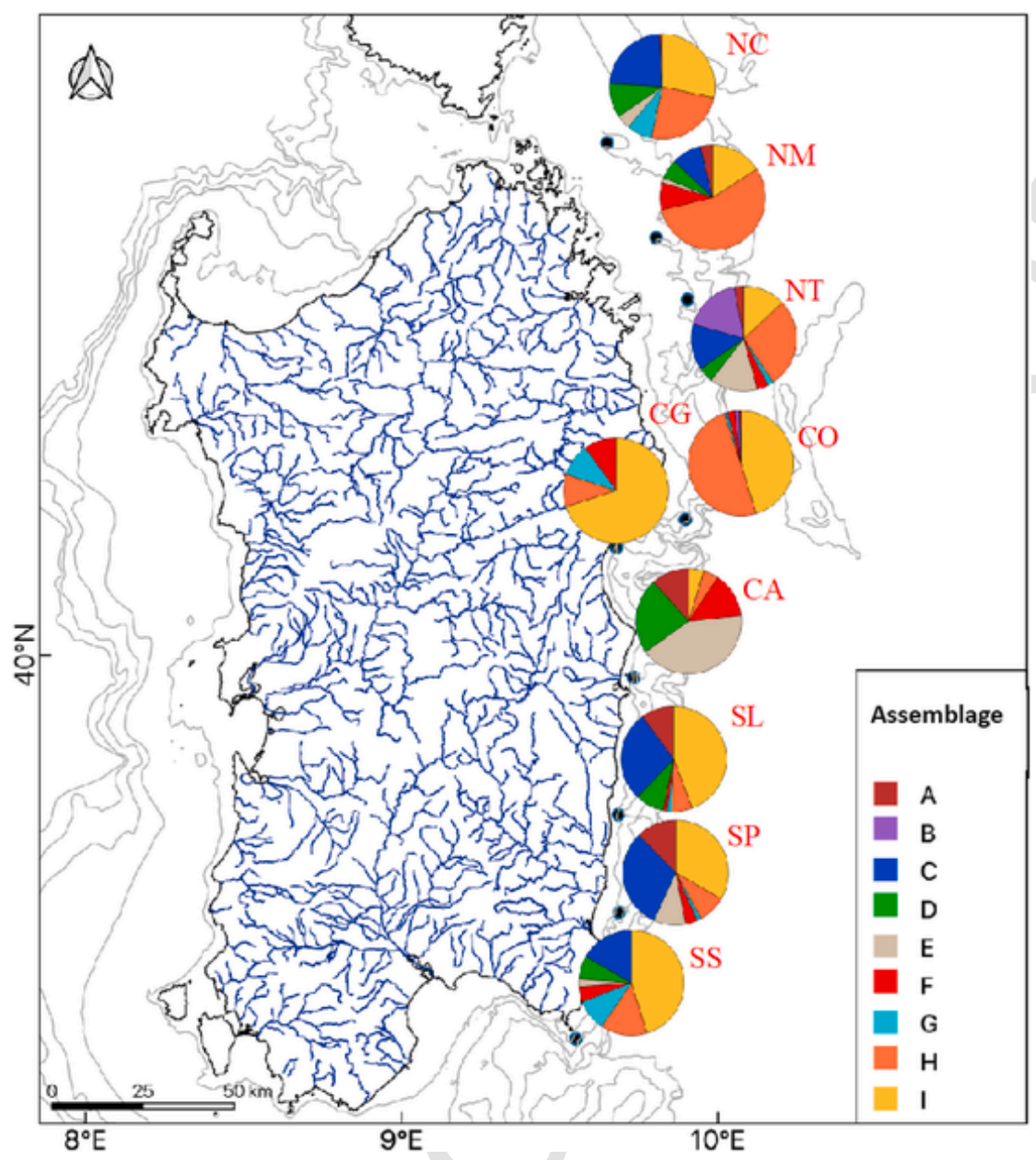

Fig. 3. Map of coral assemblages' composition within each investigated canyon.

Assemblage A was characterized by the occurrence of A. subpinnata (Fig. 5A), together with few and spread colonies of $E$. cavolinii, C. verticillata and $D$. cornigera (Table 2). The substrate characterising this assemblage was both rocky outcrops with low-silt coverage and medium-silted hard bottom, with some exceptional cases in which it was found in a high-silted substrate (Fig. 6C). This assemblage dwells mostly on vertical walls, but it was also found on inclined and flat rocky terraces (Fig. 6D), at an average depth of $162 \pm 6 \mathrm{~m}$, and at an average distance from the coast of $4.7 \pm 0.3$ nautical miles (Table 2, Fig. 6A-B). This assemblage mainly occurred in the northern canyons, NT and NM, while it was not found in the central CG and the southern SS canyons (Figs. 3 and 4). Litter items found among this assemblage were mainly plastic disposals (plastic bags and un-identify plastic pieces), together with one lost fishing net and one rope, probably belonging to some fishing gear (Fig. 6E).

Assemblage B was characterized by the dominant occurrence of the black coral L. glaberrima (Fig. 5B), followed by P. larix, and few spread colonies of A. subpinnata, A. dichotoma, E. cavolinii and A. hirsuta (Table 2). This assemblage occurred between 160 and $185 \mathrm{~m}$ depth, at an average distance from the coast of $8.2 \pm 0.5$ nautical miles, on single and multiple tall rocky outcrops, with low-silted coverage, mostly on inclined and vertical surfaces (Fig. 6A-B-C-D). This assemblage was found only in the south side of the head of NT canyon (Figs. 3 and 4), and the only litter items found were fishing longlines entangled to coral colonies (Fig. 6E).
Assemblage $\mathrm{C}$ was mainly characterized by the whip-like gorgonian V. flagellum (Fig. 5C), that forms vast meadows, followed by P. larix, $C$. verticillata and A. subpinnata (Table 2). Contrarily to the previous assemblages (A and B), assemblage C was found mostly on medium-silted and high-silted substrates, mainly on inclined and flat surface and, only in few cases, also on vertical substrates, at depth comprised between 123 and $217 \mathrm{~m}$ (Table 2, Fig. 6A-B-C-D) and at anerage distance from the coast of $5.8 \pm 0.2$ nautical miles. The $V$. flagellum assemblage occurred mostly in the southern and northern canyons, with the highest density recorded in the SP canyon $\left(8.1 \pm 0.5 \mathrm{col} \mathrm{m}^{-2}\right)$, and it was absent in the central canyons (Figs. 3 and 4). Fishing gears such as nets, together with metal and plastic items were encountered in equal percentage within this assemblage (Fig. 6E).

Assemblage D was the only monospecific assemblages, characterized by the widespread occurrence of the fan-like C. verticillata (Table 2; Fig. 5D) mainly on medium-silted boulders and cobbles, with only few colonies found on high silted and low-silted rocky substrate (Fig. 6C). The surface orientation on which this assemblage was found, mostly vertical and inclined (Fig. 6D). This assemblage was present in all the northern canyons, only CA canyon among the central canyons, in SS and SL among the southern canyons, with $C$. verticillata reaching densities up to $1.3 \pm 0.1 \mathrm{col} \mathrm{m}^{-2}$ in SL (Figs. 3 and 4). The depth range of $C$. verticillata assemblage was comprised between 111 and $196 \mathrm{~m}$ depth, at an average distance from the coast of $5.4 \pm 0.3$ nautical miles (Fig. 6A-B). Most of the litter items were lost fishing nets entangled within $C$. verticillata colonies, fol- 

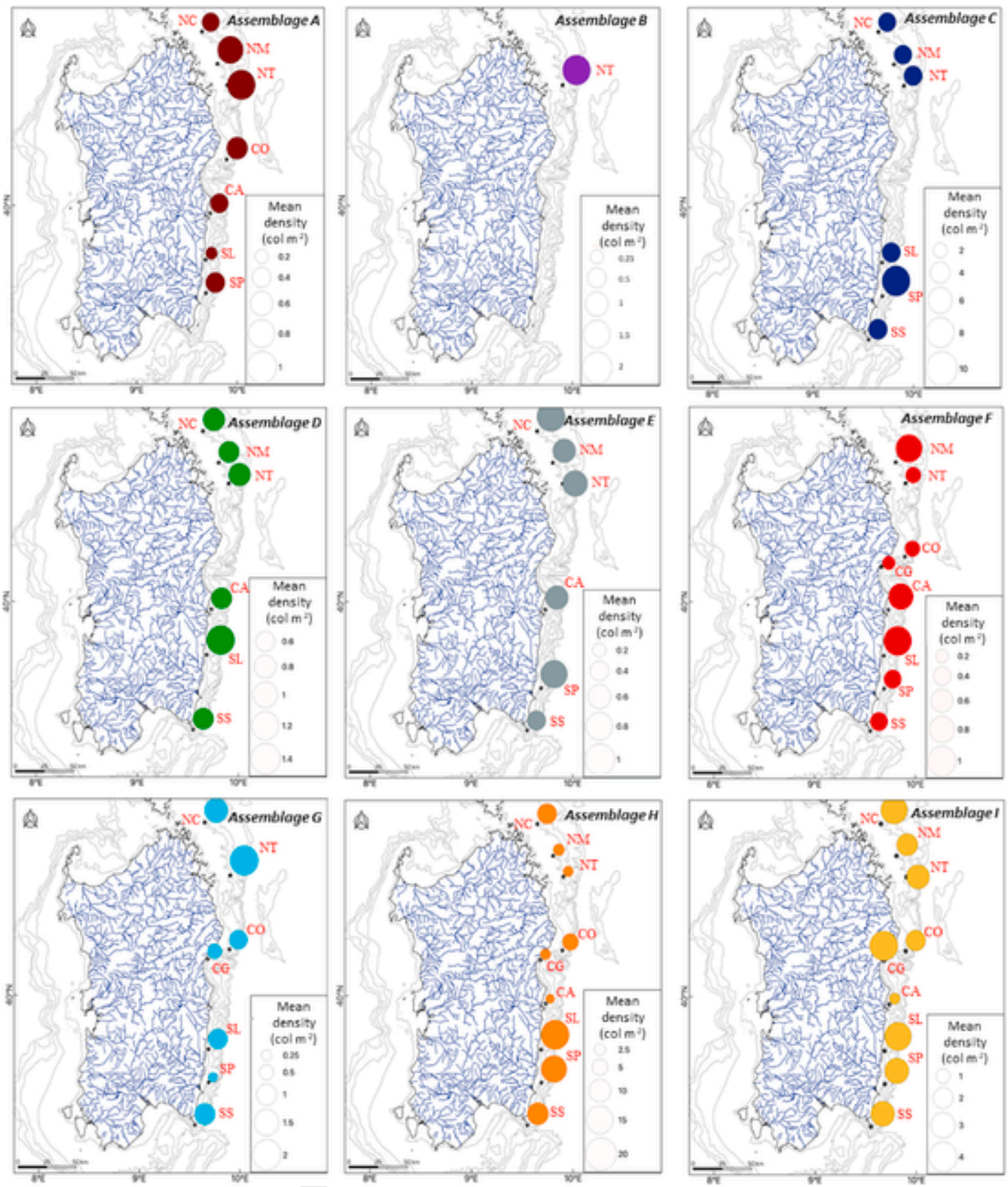

Fig. 4. Spatial distribution and mean density of the coral assemblages identified by the cluster analysis.

lowed by few ropes and few pieces of degraded plastic items (Fig. 6E).

Assemblage $\mathrm{E}$ was characterized by the high occurrence of $P$. larix (Fig. 5E), followed by colonies of $C$. verticillata and A. dichotoma. Within Assemblage $\mathrm{E}$ also colonies of $B$. mollis and E. cavolinii were recorded (Table 2). This assemblage occurred most often on inclined and vertical medium-silted rocky substrate, and less frequently on a rocky substrate with low-silt deposition and on high-silted bottom (Table 2; Fig. 6A-C-D). P. larix assemblage was found at a depth ranging from 103 to $201 \mathrm{~m}$ at an average distance from the coast of $5.6 \pm 0.3$ (Fig. 6A-B). Similar to the previous assemblage, the spatial distribution of the Assemblage $\mathrm{E}$ included all the northern canyons, only CA canyon among the central canyons, and SS and SP from the southern canyons (Figs. 3 and 4). Fishing nets and longlines were the most abundant litter items found within this assemblage, followed by few glass bottles (Fig. 6E).
Assemblage F was mostly dominated by colonies of the yellow scleractinian $D$. cornigera (Fig. 5F), together with few colonies of $E$. cavolinii and A. subpinnata (Table 2). D. cornigera colonies were found mostly on vertical rocky substrate with low-silt coverage, but in some cases also on inclined medium-silted hard bottom covered by a thin layer of sediment (Table 2; Fig. 6C-D). This assemblage was recorded in all investigated canyons, except for the NC canyon (Figs. 3 and 4), at a depth ranging from 111 to $253 \mathrm{~m}$, at an average distance from the coast of $5.4 \pm 0.4$ nautical miles (Fig. 6A-B). Litter items documented within assemblage F colonies were mostly plastic bags and fishing nets (Fig. 6E).

Assemblage $\mathbf{G}$ was mainly characterized by the high presence of the short gorgonian B. mollis (Fig. 5G) that was found dwelling together with colonies of the other target species, such as $E$. cavolinii, A. hirsuta, C. rubrum, C. verticillata, P. larix and A. subpinnata (Table 2). Assemblage $\mathrm{G}$ maximum densities were recorded in NT canyon and NC (max density $1.5 \pm 0.6 \mathrm{col} \mathrm{m}^{-2}$ ), while in other investigated 
Table 2

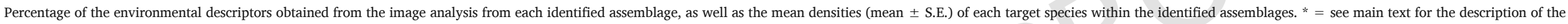
different categories.

\begin{tabular}{|c|c|c|c|c|c|c|c|c|c|c|}
\hline variable \assemblage & & & A & B & $\mathrm{C}$ & $\mathrm{D}$ & & $\mathrm{E}$ & $\mathrm{F}$ & G \\
\hline \multirow[t]{3}{*}{ silt coverage* } & & low & $50 \%$ & $100 \%$ & $15 \%$ & $7 \%$ & & $35 \%$ & $77 \%$ & $61 \%$ \\
\hline & & medium & $44 \%$ & - & $47 \%$ & $70 \%$ & & $51 \%$ & $23 \%$ & $28 \%$ \\
\hline & & high & $6 \%$ & - & $38 \%$ & $22 \%$ & & $14 \%$ & - & $11 \%$ \\
\hline \multirow[t]{4}{*}{ bottom slope* } & & flat & $14 \%$ & $7 \%$ & $25 \%$ & $13 \%$ & & $4 \%$ & $12 \%$ & \\
\hline & & inclined & $33 \%$ & $56 \%$ & $60 \%$ & $33 \%$ & & $55 \%$ & $31 \%$ & $57 \%$ \\
\hline & & vertical & $53 \%$ & $37 \%$ & $14 \%$ & $54 \%$ & & $41 \%$ & $57 \%$ & $43 \%$ \\
\hline & & overhanging & - & $->$ & - & - & & - & - & - \\
\hline \multirow[t]{11}{*}{ species densities $\left(\mathrm{col} \mathrm{m}^{-2}\right)$} & C. verticillata & & $<0.1$ & & $<0.1$ & $0.83 \pm 0.07$ & $0.32 \pm 0.08$ & & & $<0.1$ \\
\hline & $\begin{array}{l}\text { P. clavata } \\
\text { C. rubrum }\end{array}$ & & & & & & & & & $<01$ \\
\hline & V. flagellum & & & & $4.53 \pm 0.40$ & & & & & $<0.1$ \\
\hline & A. hirsuta & & & $<0.1$ & & & & & & $0.13 \pm 0.05$ \\
\hline & E. cavolinii & & $<0.1$ & $<0.1$ & & & $<0.1$ & & $<0.1$ & $0.26 \pm 0.09$ \\
\hline & B. mollis & & & & & & $<0.1$ & & & $1.35 \pm 0.22$ \\
\hline & A. subpinnata & & $0.54 \pm 0.09$ & $<0.1$ & $<0.1$ & & & & $<0.1$ & $<0.1$ \\
\hline & A. dichotoma & & & $<0.1$ & & & $0.12 \pm 0.03$ & & & \\
\hline & P. larix & & & $0.12 \pm 0.10$ & $0.17 \pm 0.03$ & & $0.68 \pm 0.03$ & & & $<0.1$ \\
\hline & L. glaberrima & & & $1.84 \pm 0.16$ & & & & & & \\
\hline & D. cornigera & & $<0.1$ & & & & & & $0.62 \pm 0.09$ & \\
\hline
\end{tabular}


Table 3

List of spieces recorded in each coral assemblage.

\begin{tabular}{|c|c|c|c|c|c|c|c|c|c|c|}
\hline phyla & SPECIES & A & B & $\mathrm{C}$ & $\mathrm{D}$ & $\mathrm{E}$ & $\mathrm{F}$ & G & $\mathrm{H}$ & I \\
\hline \multirow[t]{12}{*}{ Cnidaria } & Viminella flagellum & & & + & & & & & + & + \\
\hline & Callogorgia verticillata & + & & + & + & + & & + & + & + \\
\hline & Corallium rubrum & & & & & & & + & + & + \\
\hline & Acanthogorgia hirsuta & & + & & & & & + & + & + \\
\hline & Eunicella cavolinii & + & + & & & + & + & + & + & + \\
\hline & Bebyce mollis & & & + & & + & & + & + & + \\
\hline & Paramuricea clavata & & & & & & & & + & + \\
\hline & Parantipathes larix & & + & + & & + & & + & & + \\
\hline & Antipathes subpinnata & + & + & + & & + & + & + & & + \\
\hline & Antipathes dichotoma & & + & & & & & & & \\
\hline & Leiopathes glaberrima & & + & & & & & & & \\
\hline & Dendrophyllia cornigera & + & & & & & + & & & + \\
\hline \multirow[t]{3}{*}{ Porifera } & Poecillastra compressa & & + & + & + & + & + & + & + & + \\
\hline & Pachastrella monilifera & + & & + & & + & + & + & + & + \\
\hline & Axinella sp. & + & & + & + & + & & + & + & + \\
\hline \multirow[t]{2}{*}{ Anellida } & Filograna-Salmacina complex & & + & + & + & 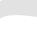 & & & + & + \\
\hline & Bonellia viridis & & + & & & & & & + & + \\
\hline Brachiopoda & Gryphus vitreus & & & & & 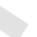 & & + & & \\
\hline \multirow[t]{3}{*}{ Crustacea } & Munida tenuimana & & & & & & & + & & \\
\hline & Palinurus elephas & & & + & + & & & + & + & + \\
\hline & Plesionika sp & & & & & & + & & & \\
\hline \multirow[t]{10}{*}{ Echinoderamta } & Astrospartus mediterraneus & & & + & 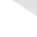 & & + & + & & \\
\hline & Peltaster placenta & & & + & & + & & + & + & + \\
\hline & Cidards & & & + & + & & + & & + & + \\
\hline & Echinus melo & & + & + & & & + & + & + & + \\
\hline & Centrostephanus longispinus & & & & & & & & & + \\
\hline & Echinaster sepositus & & & + & & + & & + & + & + \\
\hline & Hacelia attenuata & & & & & & + & + & & + \\
\hline & Holothuria sp & + & + & + & & + & + & + & + & \\
\hline & A. meditterraneus & & & + & & & & & & \\
\hline & Ophiuroidea $s p$ & & & & + & & & & & \\
\hline \multirow[t]{18}{*}{ Chordata } & Acantholabrus palloni & + & + & & + & + & & & & \\
\hline & Polyprion americanus & & & & & & & & + & \\
\hline & Helicolenus dactylopterus & & & + & + & & & + & + & \\
\hline & Capros aper & & & & & + & & & & \\
\hline & Anthias anthias & & + & & + & & + & + & + & + \\
\hline & Labrus mixtus & & + & + & & & & & & \\
\hline & Lappanella fasciata & & & + & & & & & & \\
\hline & Macroramphosus scolopax & & & + & & & & & & \\
\hline & Serranus hepatus & & & & & & & & & + \\
\hline & Phycis bleinnoides & & & + & & & & + & + & + \\
\hline & Mola mola & & & & & & & & + & + \\
\hline & Zeus faber & & & & & + & & + & & \\
\hline & Synodus saurus & & & & & + & + & & + & \\
\hline & Serranus scriba & & & & & & & & & + \\
\hline & Mullus barbatus & & & & & & & & & + \\
\hline & Scorpaena sp & + & & & & + & & & + & + \\
\hline & Galeus melastomus & & & & & + & & & & + \\
\hline & Scyliorhinus canicula & & & + & + & + & & & & + \\
\hline
\end{tabular}

canyons the density was lower and it was no found in CA and NM canyons (Figs. 3 and 4). This assemblage was found between 96 and $185 \mathrm{~m}$ depth, mostly on inclined and vertical with a low-silted substrate and occasionally in substrates with coverage of medium- and high-silted ones (Table 2; Fig. 6A-C-D). Assemblage $\mathrm{G}$ was found at an average distance from the coast of $6.5 \pm 0.6$ nautical miles, and it was impacted by the presence of several ropes (Fig. 6B-E).

Assemblage $\mathbf{H}$ was the assemblage that presented the highest density, as it was characterized by the association of the two most abundant species among the investigated target species, C. rubrum and E. cavolinii (Figure 6H). The presence of this assemblage was recorded together with less frequent occurrence of colonies of $P$. clavata, V. flagellum, C. verticillata, A. hirsuta, B. mollis (Table 2). Assemblage $\mathrm{H}$ developed almost entirely on a rocky substrate with low-silted accumulation mostly on vertical surfaces, and in few cases, it was found on hard bottom substrate with medium-silted coverage, probably deposited after the settlement of $C$. rubrum and E. cavolinii colonies (Table 2; Fig. 6C-D). C. rubrum and E. cavolinii assemblage was ubiquitous in all investigated canyons (Figs. 3 and 4), with a maximum density registered in SL canyon (up to 33.4 colonies $\mathrm{m}^{-2}$ ) at a depth ranging from 96 to $187 \mathrm{~m}$ and at an average distance from the coast of $6.7 \pm 0.1$ nautical miles (Fig. 6A-B). Assemblage 

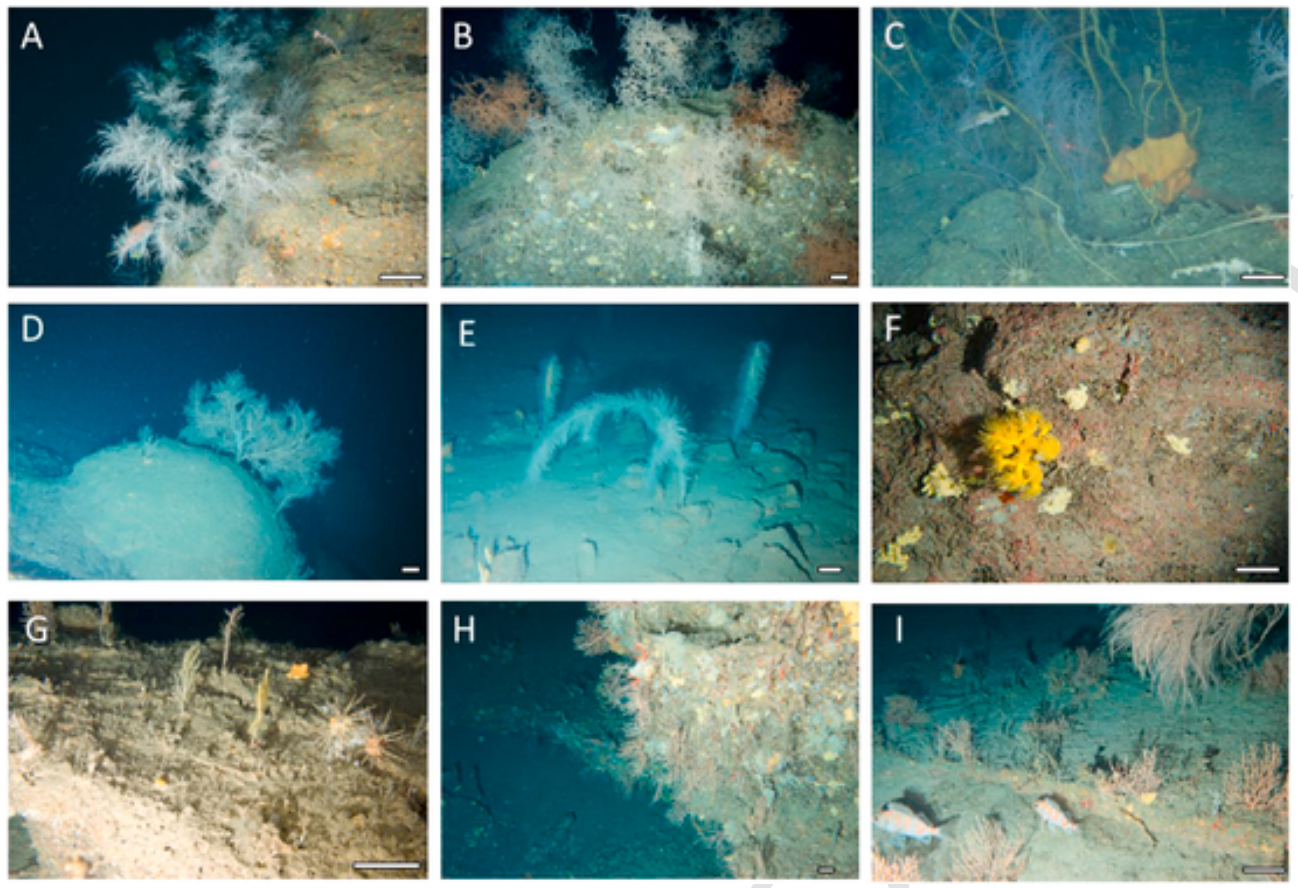

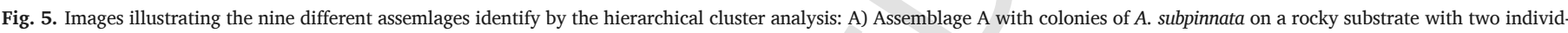

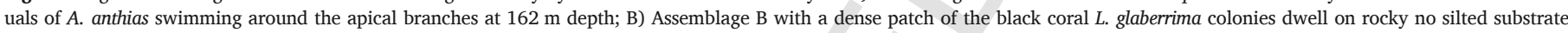

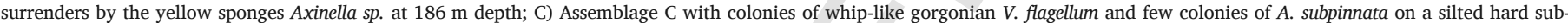

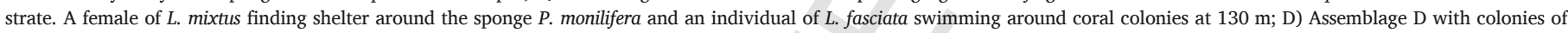

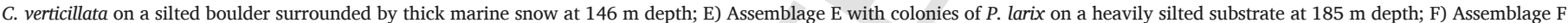

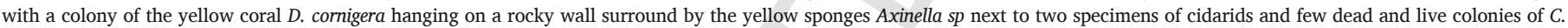

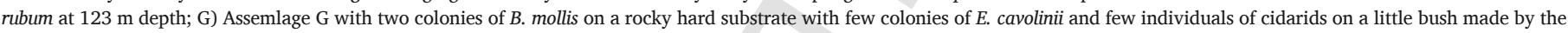

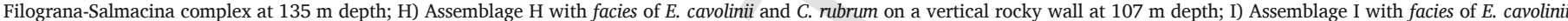

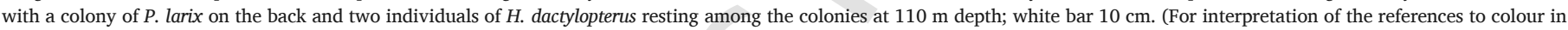
this figure legend, the reader is referred to the Web version of this article.)

G was impacted by several fishing nets, followed by ropes and a few plastic items (Fig. 6E).

Assemblage I was ubiquitous and the most heterogenous one (Figs. 3 and 4), characterized by the dominant occurrence of $E$. cavolinii (Fig. 5I), followed by C. verticillata and then by V. flagellum, C. rubrum, A. hirsuta, B. mollis, $P$. clavata, $P$. larix, A. subpinnata and D. cornigera (Table 2 ). This assemblage was observed at an average distance of $5.5 \pm 0.1$ nautical miles from the coast, between 86 and $197 \mathrm{~m}$ depth, mainly on rocky vertical and inclined substrate with low-silted sedimentation coverage and in few cases on medium-silted substrate (Table 2; Fig. 6A-B-C-D). Assemblage I was the most heterogeneous one, also considering the composition of litter items found deposited within its coral colonies. Lost fishing nets were the most abundant type of litter found, followed by ropes, plastic bags, glass bottles and metal items; the less abundant item found was fishing longline (Fig. 6E).

\subsection{Spatial variation of coral assemblages}

Coral assemblages' density and coral assemblages' composition did not vary between the northern, the central and the southern areas (Table 4). At the same time, significant differences were found among canyons within each area both for coral asseblages' density and composition (Table 4).

The separate analysis of each area with SIMPER revealed that variations within each northern canyon are mostly due to changes in the density of Assemblage I in NC, and Assemblage H in NM and NT. In contrast, differences in the composition of the coral assemblages among the three northern canyons are mostly explained by variations in the density of Assemblage H (Table 5). The SIMPER analysis also showed that the percentage of dissimilarity in the composition of coral assemblages at the scale of area - among the canyons -(87-90\%) is slightly higher than that at the scale of each single northern canyon (77-88\%).

In the central area, the SIMPER analysis revealed that variations within each canyon are mostly due to changes in the density of Assemblage I in CO and CG, and of Assemblage E in CA, while differences in the compositions of the coral assemblages are mostly explained by the variations in the density of the Assemblage I (Table 5). From the SIMPER analyses also emerged that, as for the northern canyons, the percentage of dissimilarity of coral assemblages among the central canyons (69-96\%) is higher than within each single central canyon (60-90\%).

In the southern area, the results of the SIMPER analysis showed that variations within and among southern canyons are mostly due to changes in the density of Assemblage I (Table 5). The SIMPER analyses also showed that the percentage of dissimilarity in the composition of coral assemblages at the scale of area (80-84\%) is almost the same than that at the scale of each single southern canyon (74-82\%).

\subsection{Relationships between coral assemblages and environmental variables}

According to the results of the distance linear model selected by DistLM in the northern canyons, $19.22 \%$ of the variability in coral assemblages' composition was explained by silt coverage and water 


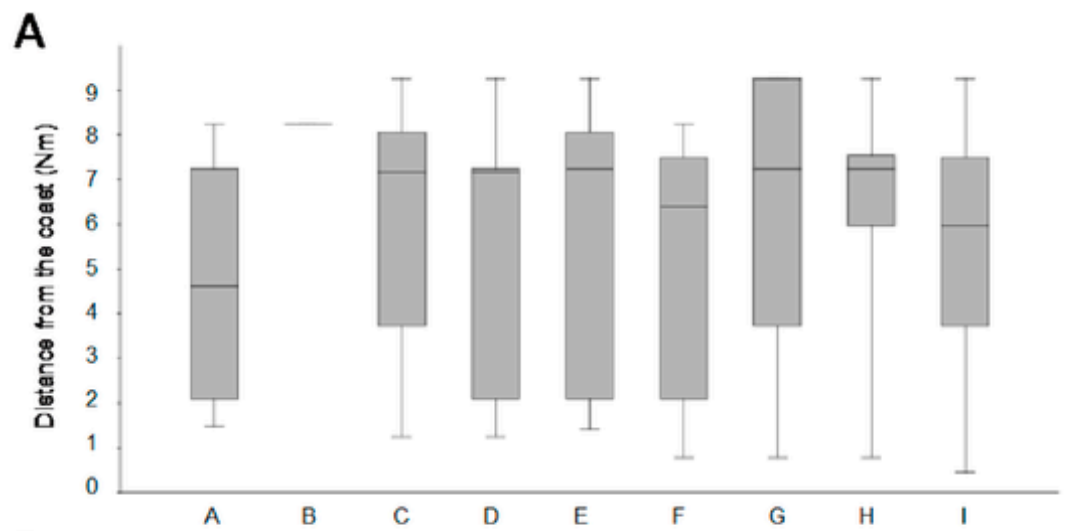

B

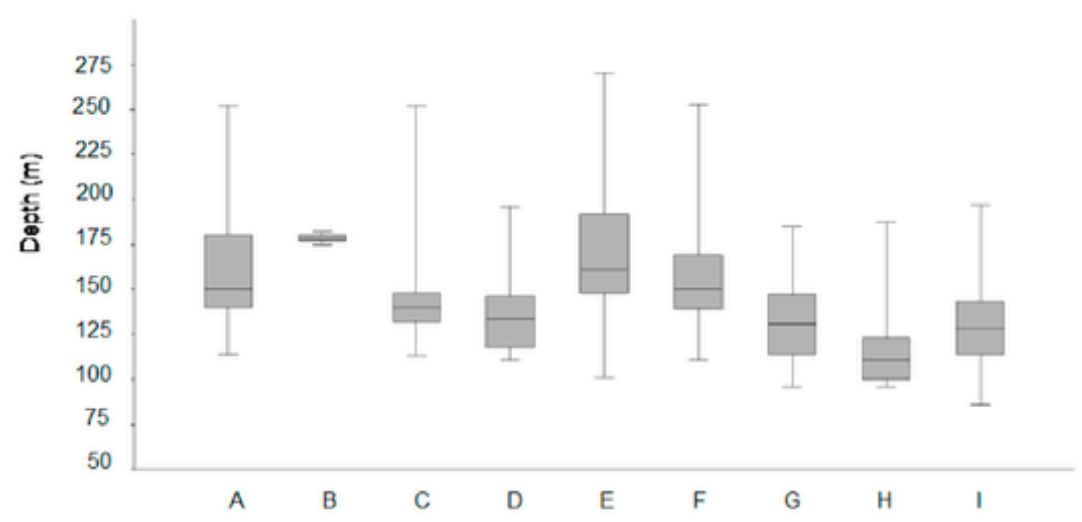

C

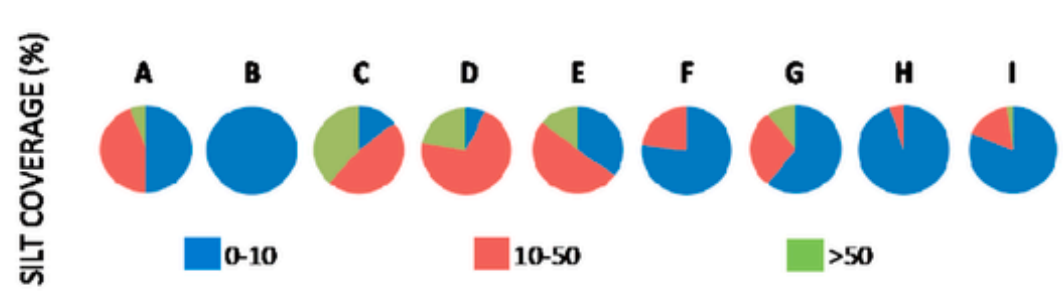

D

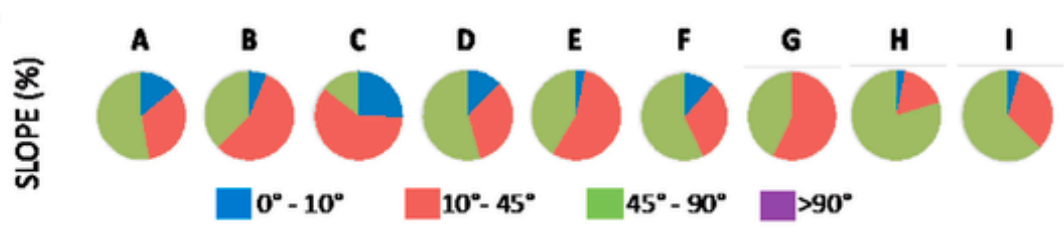

E

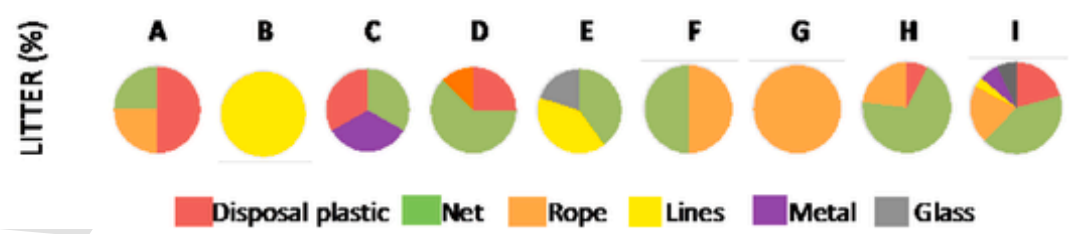

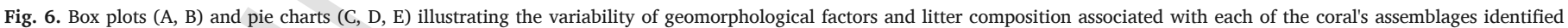
from the cluster analysis.

depth as variables that most significantly contributed to the observed differences ( 14.5 and $3.5 \%$ respectively), while the other variables contributed for less than 1\% (Table 6). The dbRDA ordination plot showed that the variable silt coverage mainly structured the samples along the first axis, while water depth structured the samples along the second axis. All the other variables showed a minor positive correlation (short vectors in length Fig. 7A).
Regarding central canyons, the results of the distance linear model explained a total of $18.48 \%$ of the variation in coral assemblages' composition and identified distance from the coast (11.9\%) and depth $(5.42 \%)$ as variables that most significantly contributed to the observed differences, while slope and silt coverage contributed for $<1 \%$ (Table 6). The dbRDA ordination plot showed that the dis- 
Table 4

Results of the PERMANOVA analysis testing for differences in the coral assemblages' density and coral assemblages' composition among areas and canyons within areas. Bray-Curtis similarity matrix; $\mathrm{df}=$ degrees of freedom; $\mathrm{MS}=$ mean square; Pseudo-F = Permutational F; ${ }^{* * *}=\mathrm{P}<0.001$; ns $=$ not significant.

\begin{tabular}{lclll}
\hline \multicolumn{1}{l}{ Coral assemblages' density } & & & \\
\hline Source & df & MS & Pseudo-F & P(perm) \\
\hline Area & 2 & 5966.6 & 1.985 & $\mathrm{~ns}$ \\
Canyon (Area) & 6 & 4174.4 & 6.684 & $* * *$ \\
Res & 925 & 624.45 & & \\
Total & 933 & & & \\
Coral assemblages' composition & & & P(perm) \\
Source & df & MS & Pseudo-F & \\
Area & 2 & 66144 & 1.884 & \\
Canyon (Area) & 6 & 50522 & 13.782 & \\
Res & 925 & 3665.7 & & \\
Total & 933 & & & \\
\hline
\end{tabular}

tance from the coast mainly structured the samples along the first axis with a partial segregation of data between assemblages $\mathrm{H}$ and I from the other assemblages. Depth structured the samples along the second axis, with no clear segregation among assemblages (Fig. 7B).

Among the southern canyons, the DistLM model revealed that the combined effect of the identified environmental variables explains $14.74 \%$ of the total variation. The variables that most significantly contributed to the variation were: silt coverage $(11.80 \%)$ and water depth $(2.12 \%)$, while distance from the coast and slope contributed significantly $<1 \%$ to explain variation on the coral assemblages (Table 6). Similar to the northern canyons, the dbRDA ordination plot showed that the variable substrate mainly structured the samples along the first axis, while water depth structured the samples along the second axis (Fig. 7C).

\section{Discussion}

The ecological relevance of mesophotic MAFs in temperate habitats has been described in numerous studies (Orejas et al., 2009; Henry et al., 2013; Rossi, 2013; Fabri et al., 2014; Cerrano et al., 2015; Cau et al., 2017b; De Clippele et al., 2019), together with their recognition as Essential Fish Habitats (European Commission, STECF, 2006; D'Onghia et al., 2012; Gomes-Pereira et al., 2017) and as elements of Vulnerable Marine Ecosystems (UNGA, 2006; FAO, 2016). However, due to the increase of the anthropogenic pressures, such as bottom fishing and water pollution, semi-pristine animal forests are declining, especially in the Mediterranean Sea (Cerrano et al., 2019; Bo et al., 2015). In this regard, our investigation provides a comparative analysis among MAFs dwelling along complex geomorphological structures, such as submarine canyon systems. Mediterranean canyons are more closely spaced, more dendritic, shorter and steeper than those from other regions of the world (Harris and Whiteway, 2011). These features are perfectly represented in the eastern coast of Sardinia. Addressing how patterns of biodiversity vary across different spatial scales is crucial for assessing sound in situ conservation strategies for vulnera-

Table 5

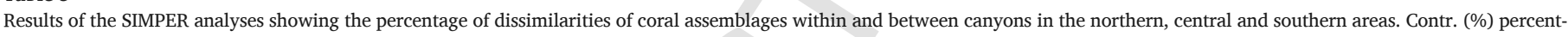
age of explained dissimilarity attributable to the i assemblages. Cum. (\%) cumulative percentage of explained variance.

\begin{tabular}{|c|c|c|c|c|c|c|c|c|c|}
\hline \multicolumn{5}{|c|}{ Within canyons } & \multicolumn{5}{|c|}{ Among canyons } \\
\hline Canyon & Diss. (\%) & Assemblage $i$ responsible & Contr. (\%) & Cum. (\%) & Contrast & Diss. (\%) & Assemblage $i$ responsible & Contr. (\%) & Cum. (\%) \\
\hline NORTH & & & & & NORTH & & & & \\
\hline \multirow[t]{3}{*}{ NC } & 83.9 & I & 41.0 & 41.0 & NC vs. NM & 86.6 & $\mathrm{H}$ & 36.2 & 36.2 \\
\hline & & $\mathrm{C}$ & 24.9 & 65.9 & & & I & 24.3 & 60.5 \\
\hline & & $\mathrm{H}$ & 24.3 & 90.3 & & & $\mathrm{C}$ & 19.0 & 79.5 \\
\hline \multirow[t]{3}{*}{ NM } & 77.2 & $\mathrm{H}$ & 83.7 & 83.7 & NC vs. NT & 89.8 & $\mathrm{H}$ & 24.7 & 24.7 \\
\hline & & I & 9.1 & 92.8 & & & I & 22.9 & 47.6 \\
\hline & & & & & & & $\mathrm{C}$ & 19.8 & 67.5 \\
\hline \multirow[t]{3}{*}{ NT } & 87.8 & $\mathrm{H}$ & 35.1 & 35.1 & NM vs. NT & 87.3 & $\mathrm{H}$ & 34.5 & 34.5 \\
\hline & & B & 25.1 & 60.2 & & & I & 15.3 & 49.8 \\
\hline & & $\mathrm{E}$ & 13.9 & 74.1 & & & $\mathrm{C}$ & 14.6 & 64.5 \\
\hline CENTRAL & & & & & CENTRAL & & & & \\
\hline \multirow[t]{3}{*}{$\mathrm{CO}$} & 67.7 & I & 59.2 & 59.2 & CO vs. CG & 68.7 & I & 46.6 & 46.6 \\
\hline & & $\mathrm{H}$ & 40.7 & 99.9 & & & $\mathrm{H}$ & 41.1 & 87.7 \\
\hline & & & & & & & G & 6.7 & 94.3 \\
\hline \multirow[t]{3}{*}{ CG } & 60.3 & I & 100.0 & 100.0 & $\mathrm{CO}$ vs. CA & 96.2 & I & 32.0 & 32.0 \\
\hline & & & & & & & $\mathrm{H}$ & 31.8 & 63.8 \\
\hline & & & & & & & $\mathrm{E}$ & 14.0 & 77.8 \\
\hline \multirow[t]{3}{*}{ CA } & 80.4 & $\mathrm{E}$ & 55.2 & 55.2 & CA vs. CG & 96.4 & I & 44.0 & 44.0 \\
\hline & & A & 23.5 & 78.7 & & & $\mathrm{E}$ & 15.6 & 59.7 \\
\hline & & $\mathrm{D}$ & 15.6 & 94.3 & & & A & 9.4 & 69.0 \\
\hline SOUTH & & & & & SOUTH & & & & \\
\hline \multirow[t]{3}{*}{ SL } & 74.3 & I & 68.0 & 68.0 & SL vs. SP & 79.6 & I & 37.5 & 37.5 \\
\hline & & C & 28.5 & 96.5 & & & C & 34.0 & 71.7 \\
\hline & & & & & & & $\mathrm{H}$ & 11.9 & 83.4 \\
\hline \multirow[t]{3}{*}{ SP } & 82.1 & I & 48.0 & 48.0 & SL vs. SS & 79.5 & I & 40.9 & 40.9 \\
\hline & & $\mathrm{C}$ & 38.6 & 86.6 & & & $\mathrm{C}$ & 28.3 & 69.3 \\
\hline & & A & 5.5 & 92.1 & & & $\mathrm{H}$ & 13.7 & 83.0 \\
\hline \multirow[t]{3}{*}{ SS } & 82.2 & I & 81.3 & 81.3 & SP vs. SS & 84.2 & I & 34.1 & 34.1 \\
\hline & & $\mathrm{C}$ & 8.6 & 89.8 & & & $\mathrm{C}$ & 28.6 & 62.7 \\
\hline & & $\mathrm{H}$ & 5.3 & 95.2 & & & $\mathrm{H}$ & 15.4 & 78.1 \\
\hline
\end{tabular}


Table 6

Results from sequential tests of the Distance based multivariate analysis for a Linear Model (DistLM). The following abbreviations are used: Pseudo-F = Permutational F; $* * *=\mathrm{P}<0.001 ; * *=\mathrm{P}<0.01 ; *=\mathrm{P}<0.05$; ns = not significant; Prop. (\%) percentage of explained variation; Cumul. (\%) cumulative percentage of total variation.

\begin{tabular}{llllll}
\hline Variables & AIC & $\begin{array}{l}\text { Pseudo- } \\
\text { F }\end{array}$ & P & $\begin{array}{l}\text { Prop. } \\
(\%)\end{array}$ & $\begin{array}{l}\text { Cumul. } \\
(\%)\end{array}$ \\
\hline Northern canyons & & & & & \\
Silt coverage & 4009.6 & 65.282 & $* * *$ & 14.54 & 14.54 \\
Depth & 3978.1 & 34.448 & $* * *$ & 3.46 & 17.99 \\
Slope & 3972.5 & 7.6036 & $* * *$ & 0.97 & 18.96 \\
Distance from the coast & 3972.1 & 2.3725 & $* *$ & 0.69 & 19.22 \\
Central canyons & & & & & \\
Distance from the coast & 2012.8 & 23.399 & $* * *$ & 11.92 & 11.92 \\
Depth & 1995.8 & 19.497 & $* * *$ & 5.42 & 17.34 \\
Slope & 1990.9 & 6.8548 & $* *$ & 0.93 & 18.26 \\
Silt coverage & 1990.6 & 2.2454 & $*$ & 0.22 & 18.48 \\
Southern canyons & & & & & \\
Silt coverage & 1585 & 17.647 & $* * *$ & 11.80 & 11.80 \\
Depth & 1580.5 & 10.666 & $* * *$ & 2.12 & 13.92 \\
Distance from the coast & 1576.3 & 2.1967 & $*$ & 0.55 & 14.47 \\
Slope & 1576.1 & 1.4332 & $*$ & 0.27 & 14.74 \\
\hline
\end{tabular}

ble assemblages such as those object of our study (Levin et al., 2010; Schlacher et al., 2010; Harris and Whiteway, 2011; Danovaro et al., 2010, 2014; Fabri et al., 2014; Casas-Güell et al., 2015; Cau et al., 2017c).

Based on the high heterogeneity of submarine canyons at multiple spatial scales, we would expect that the composition of coral assemblages would vary among different submarine canyons located in different areas. However, our results showed that most of the variability occurred at the smallest spatial scale: among canyons within each area, rather than among different geographical areas. The same pattern has been already observed for megafaunal assemblages, in terms of both MFAs and bentho-pelagic taxa, in the Mediterranean Sea (Pierdomenico et al., 2019). Focusing specifically on MAFs, our results are in accordance with observations reported by Cau et al. (2017c) where differences in abundance, distribution and biodiversity of MAFs dwelling in two different geomorphological features (submarine canyons and rocky pinnacles) were found to be lower compared to the diversity observed within each geomorphology.

The facies of $E$. cavolinii and its association with C. rubrum (Assemblages $\mathrm{I}$ and $\mathrm{H}$ ) were present in all the investigated canyons dwelling on inclined and steep rocky walls, as well as hanging on small rocky caves and crevices. These two assemblages are typically found on rocky substrates mostly with no silt coverage and exposed to strong currents, as also previously reported (Gori et al., 2011; Cau et al., 2015, 2016; Enrichetti et al., 2019). Assemblage F (D. cornigera) was mostly found on a substrate with low sedimentation cover, while in several other studies it was reported on highly silty substrates (Castellan et al., 2019; Enrichetti et al., 2019), highlighting the adaptability of this species to different environmental condition. When the presence of accumulated sediment increased and the substrate inclination decreased, dense patches of Assemblage C ( $V$. flagellum), D ( C. verticillata) and A (A. dichotoma) became dominant, enhancing the three-dimensional complexity of the habitat and allowing a rich benthic and benthic-pelagic associated fauna to find shelter and feeding grounds, e.g., A. anthias, L. mixtus and L. fasciata. The association between theses corals assemblages and a rocky silted horizontal substrate has been documented in other studies, usually in areas with slow currents and slightly turbulent conditions (Giusti et al., 2017; Bo et al., 2013; Cau et al., 2017c).

The presence of seafloor litter has been documented in all the investigated assemblages. In most cases, several categories of litter were found together, with the exception of assemblages B and G, which were characterized exclusively by Derelict Fishing Gears (DFGs) such as longlines and ropes. The ubiquitous incidence of impacted assemblages in every investigated canyon confirms how submarine canyons act as natural conduit also for anthropogenic material, from the shelf to the abyssal plain (Orejas et al., 2009; Schlining et al., 2013; Pham et al., 2014; Cau et al., 2018). As for other studies, derelict fishing gears such as nets, longlines and ropes were the most abundant items compared to the other litter items found (Cau et al., 2017a; Giusti et al., 2019). Ghost nets, longlines and ropes, in most of the cases, were found entangled around and above coral colonies, confirming how these assemblages are useful indicators of the presence and the negative interaction of seafloor litter with benthic fauna (Galgani et al., 2018). In addition to this physical disturbance, synthetic fibres from nets and DFGs, in general, can proceed in their fragmentation process, which allow particles to be bio-available to benthic fauna or can accumulate in sediments (Van Cauwenberghe et al., 2013; Woodall et al., 2014; Cau et al., 2020). However, in a few cases, these items also provided substrates for benthic organism's colonization. Pierdomenico et al. (2019) also reported the role of litter accumulations as a refuge area for some fish species. Despite this, the large presence of DFGs found in this study highlighted how coral assemblages are continuously threatened by both active and passive fishing practice impacts, confirming what has been previously reported in numerous studies within and outside the Mediterranean Sea (D'Onghia et al., 2012; 2017; Sampaio et al., 2012).

With regard to the three geographic areas studied, there was no significant difference in terms of corals assemblages' densities and coral assemblages' composition. This homogeneity is due to the ubiquitous presence of the Assemblages $\mathrm{H}$ and $\mathrm{I}$ (the associations dominated by $E$. cavolinii and $C$. rubrum), with the last one being the most frequent in the southern area and progressively decreasing northward.

Southern and northern canyons showed the occurrence of silty/ sandy bottom's associated assemblage C (dominated by V. flagellum), that was absent in the central area. The central area was characterized by the peculiar composition of the CA canyon, the only one characterized by the dominance of Assemblages C, D and E. The peculiarity of CA canyon could be due to the presence of a big river (Riu Pramaera) that flows right in front of the canyon. The presence of the river could increase the terrestrial sediment transportation and silt deposition favouring species such as $V$. flagellum, $P$. larix and $C$. verticillata, known to show an affinity for silted environments (Cau et al., 2017c; Giusti et al., 2017). Similarly, the NT canyon, was unique in the northern area, showing the highest habitat heterogeneity in terms of substrate and silt accumulation and the highest assemblages' heterogeneity in terms of number of coral species (Fig. 3, Table 5). NT canyon was characterized by a complex geomorphological framework, with a rectilinear path of gullies and arcuate slide scars along the canyon walls, harbouring dense patches of $C$. rubrum and $E$. cavolinii (Assemblage $H$ ), together with a dense forest of L. glaberrima (Assemblage B) on big rocky boulders. In Sardinia, the presence of the long-lived black coral L. glaberrima was documented only in the southwestern margin of the island of Sardinia, where the canopy of black corals serves as a spawning ground for the spotted catshark $S$. canicula (Cau et al., 2017b). Another important factor that might influence the presence and the distribution of coral assemblages in this canyon is the presence of the Levantine Intermediate Water (LIW) current, that was shown as the current that shapes 

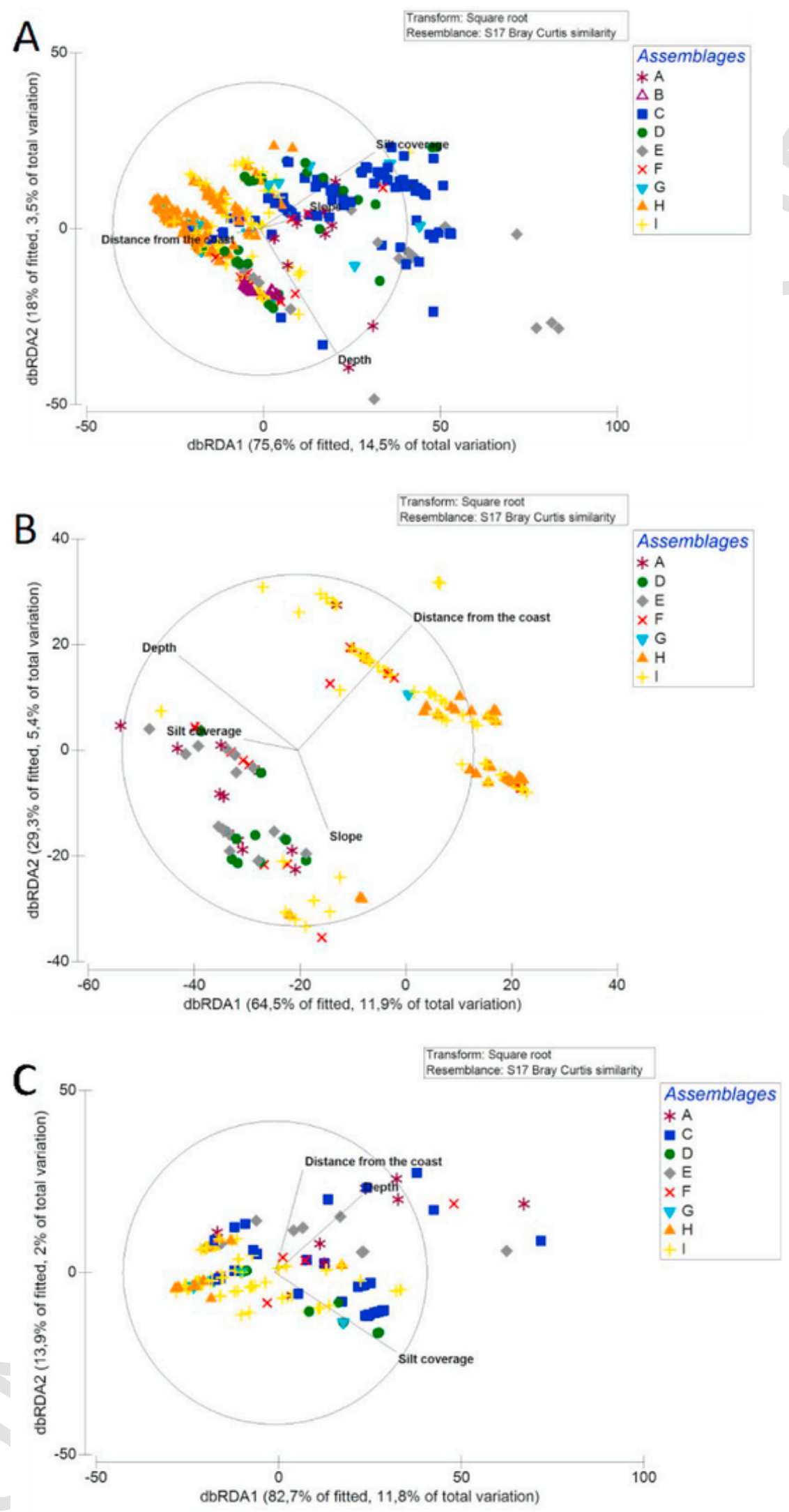

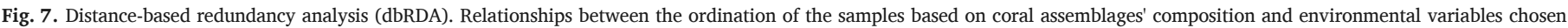
by the DistLM analyses, from Northern (A) Central canyons (B) and Southern (C) areas. Variables best explaining density variations are reported in the graph as vectors. 
and links deep-sea coral assemblages around Sardinia island (Freiwald et al., 2009; Taviani et al., 2017; Chimienti et al., 2019; Moccia et al., 2019). The new findings presented in this study further corroborate the important role of these water currents, that can supply food to the corals, facilitate the larva transport and contributing to counteract sedimentation, also among coral's assemblages at shallower depths.

Discerning which biotic and abiotic factors drive spatial biodiversity patterns is a difficult task, especially in the deep sea. This is not surprising considering the different biological factors and the various environmental and geomorphological features characterizing each canyon ecosystem. An increasing number of studies identified biological factors such as recruitment, larval dispersal, competition for space and resources or human disturbances as crucial drivers of diversity patterns in several Mediterranean marine habitats (Casas-Güell et al., 2015; Cau et al., 2016). This is particularly true for benthic suspension feeders which show a low dispersal capability and a long-life cycle that, potentially, could shape the community composition for extended periods after a thriving reproductive pulse (Garrabou and Harmelin, 2002). Numerous recent studies have shown that benthic species show preferences for certain depths and topographic conditions, in response to their distinctive (or peculiar) biological characteristics (Pierdomenico et al., 2019). In the present study, the results of the distance linear model selected by DistLM identified silt coverage and water depth as variables that significantly contributed to the observed differences in the northern and southern areas. While distance from the coast and water depth were identified for the central area. Silt coverage resulted an important explanatory variable in shaping coral communities, as also previously reported for roche du large formations in the continental shelf (Cau et al., 2015; Giusti et al., 2017) (Table 6). Similarly, the role of water depth in the deep-sea coral zonation is in agreement with previous studies conducted in the Mediterranean Sea (D'Onghia et al., 2003; Duffy et al., 2014; Corbera et al., 2019). However, knowing that some coral species can have an extended range of depth distribution (e.g, Corallium rubrum), water depth can be considered as a proxy of other abiotic factors, such as temperature, current regime and trophic supply. Among these factors, water current is the most variable at local scale, as it influences the settlement and the feeding of the corals, as well as the amount of silt coverage (Gori et al., 2015; De Clippele et al., 2017; Rossi et al., 2019). This can be the reason why the contribution of silt coverage and depth in explaining variations in assemblages was different for the three investigated areas. Moreover, distance from the coast identified by the results of DistLM as a significant variable for the central area, which comprises canyons at different distances from the coast (range 0.4-6.2 Nm), could be due to a different incidence of perturbations (both environmental and anthropogenic) occurring within canyon systems (Fanelli et al., 2018), especially in the sites closest to the coast. Such kind of perturbations can alter the distribution of long-lived benthic fauna, thus facilitating more adaptable species that may have a competitive advantage in perturbed habitats.

Finally, our results suggest that the area under scrutiny is relatively homogeneous in terms of coral assemblages' composition, with differences apparently constrained by hydrodynamic conditions operating at the local scale.

\section{Conclusion}

The new findings presented in this study suggest that different hydromorphological processes acting at the scale of each investigated canyons, determine different sediment coverage conditions at different water depths, thus favouring the presence of diversified MAF assemblages along the canyon axis. Mapping MFA assemblages represents one of the fundamental tools for defining areas to be protected in the deep sea in a context of increasing anthropogenic and climatic threats. This is true for habitat formed by ecosystem engineers since their degradation, after certain threholds, could be irreversible. The loss of those habitats would represent a loss of important refugia for commercial and non-commercial demersal fauna, altering trophodynamic mechanism and leading towards impoverishment of the entire ecosystem. Under the perspective of management and conservation of marine resources, the results obtained in this study highlight the need for increased attention towards impacted regions and vulnerable living habitat such as those represented by marine animal forest assemblages.

\section{Uncited references}

\section{Declaration of competing interest}

The authors declare that they have no known competing financial interests or personal relationships that could have appeared to influence the work reported in this paper.

\section{Acknowledgements}

We would like to thank professor Katell Guizien for giving inspirational ideas and constructive comments during the elaboration of this paper. Furthermore, we would like to thank the crew and researchers of the R/V Astrea for precious help during ROV operations. This study was conducted in the framework of two projects focused on the investigation of coralligenous habitats and red coral, financed by the Ministry of Instruction, University and Research (MIUR; grant 2010Z8HJ5M_011 PRIN 2010-2011) and Autonomous Region of Sardinia (RAS) respectively.

\section{References}

Aguiliar, R., 2004. The Corals of the Mediterranean. Oceana, Fundacion Biodiversidad.

Altuna, A., Poliseno, A., 2019. Taxonomy, genetics and biodiversity of mediterranean deep-sea corals and cold-water corals. In: Orejas, C., Jiménez, C. (Eds.), Mediterranean Cold-Water Corals: Past, Present and Future. In: Coral Reefs of the World, 9. Springer, Cham, pp. 121-156. doi:10.1007/978-3-319-91608-8_14.

Anderson, M.J., 2001. A new method for non-parametric multivariate analysis of variance. Austral Ecol. 26, 32-46. doi:10.1111/j.1442-9993.2001.01070.pp.x.

Baillon, S., Hamel, J.F., Wareham, V.E., Mercier, A., 2012. Deep cold-water corals as nurseries for fish larvae. Front. Ecol. Environ. 10 (7), 351-356. doi:10.1890/120022.

Bianchi, C.N., Parravicini, V., Montefalcone, M., Rovere, A., Morri, C., 2012. The challenge of managing marine biodiversity:a practical tool kit for a cartographic, territorial approach. Diversity 4, 419-452. doi:10.3390/d4040419.

Bo, M., Cerrano, C., Canese, S., Salvati, E., Angiolillo, M., Santangelo, G., Bavestrello, G., 2013. The coral assemblages of an off-shore deep Mediterranean rocky bank (NW Sicily, Italy). Mar. Ecol. 1, 11. doi:10.1111/maec.12089.

Bo, M., Bavestrello, G., Angiolillo, M., Calcagnile, L., Canese, S., Cannas, R., Cau, A., Elia, M.D., Oriano, F.D., Follesa, M.C., Quarta, G., Cau, A., 2015. Persistence of pristine deep-sea coral gardens in the Mediterranean sea ( SW Sardinia ). PloS One 1-21. doi:10.1371/journal.pone.0119393.

Bramanti, L., Santangelo, G., Benedetti, M.C., Iannelli, M., Guizien, K., 2019. Demography and conservation of deep corals: the study of population structure and dynamics. In: Orejas, C., Jiménez, C. (Eds.), Mediterranean Cold-Water Corals: Past, Present and Future. Coral Reefs of the World. Springer, Cham.

Buhl-Mortensen, L., Vanreusel, A., Gooday, A.J., Levin, L.A., Priede, I.G., Buhl-Mortensen, P., Gheerardyn, H., King, N.J., Raes, M., 2010. Biological structures as a source of habitat heterogeneity and biodiversity on the deep ocean margins. Mar. Ecol. 31, 21-50. doi:10.1111/j.1439-0485.2010.00359.x.

Campanyà-Llovet, N., Snelgrove, P.V.R., De Leo, F.C., 2018. Food quantity and quality in Barkley Canyon (NE Pacific) and its influence on macroinfaunal community structure. Prog. Oceanogr. 169, 106-119. doi:10.1016/j.pocean.2018.04.003.

Canals, M., Puig, P., Durrieu de Madron, X., Heussner, S., Palanques, A., Fabres, J., 2006 Flushing submarine canyons. Nature 444, 354-357. doi:10.1038/nature05271.

Canals, M., Danovaro, R., Luna, G.M., 2019. Recent advances in understanding the ecology and functioning of submarine canyons in the Mediterranean Sea. Prog. Oceanogr. 179, 102171. doi:10.1016/j.pocean.2019.102171.

Carugati, L., Lo Martire, M., Danovaro, R., 2019. Patterns and drivers of meiofaunal assemblages in the canyons polcevera and bisagno of the ligurian sea (NW 
Mediterranean sea). Prog. Oceanogr. 175, 81-91. doi:10.1016/j.pocean.2019.03.010.

Casas-Güell, E., Teixidó, N., Garrabou, J., Cebrian, E., 2015. Structure and biodiversity of coralligenous assemblages over broad spatial and temporal scales. Mar. Biol. 162, 901-912. doi:10.1007/s00227-015-2635-7.

Castellan, G., Angeletti, L., Taviani, M., Montagna, P., 2019. The yellow coral Dendrophyllia cornigera in a warming ocean. Frontiers in Marine Science 6, 1-9. doi:10.3389/fmars.2019.00692.

Cau, A., Follesa, M.C., Moccia, D., Alvito, A., Bo, M., Angiolillo, M., Canese, S., Paliaga, E.M., Orrù, P.E., Sacco, F., Cannas, R., 2015. Deepwater corals biodiversity along roche du large ecosystems with different habitat complexity along the south Sardinia continental margin (CW Mediterranean Sea). Marine Biolology 162, 1865-1878. doi:10.1007/s00227-015-2718-5.

Cau, A., Bramanti, L., Cannas, R., Follesa, M.C., Angiolillo, M., Canese, S., Bo, M., Cuccu, D., Guizien, K., 2016. Habitat constraints and self-thinning shape Mediterranean red coral deep population structure: implications for conservation practice. Sci. Rep. 6, 1-10. doi:10.1038/srep23322.

Cau, A., Alvito, A., Moccia, D., Canese, S., Pusceddu, A., Rita, C., Angiolillo, M., Follesa, M.C., 2017. Submarine canyons along the upper Sardinian slope (Central Western Mediterranean) as repositories for derelict fishing gears. Mar. Pollut. Bull. 123, 357-364. doi:10.1016/j.marpolbul.2017.09.010.

Cau, A., Follesa, M.C., Moccia, D., Bellodi, A., Mulas, A., Bo, M., Canese, S., Angiolillo, M., Cannas, R., 2017. Leiopathes glaberrima millennial forest from SW Sardinia as nursery ground for the small spotted catshark Scyliorhinus canicula. Aquat. Conserv. Mar. Freshw. Ecosyst. 27 (3), 731-735. doi:10.1002/aqc.2717.

Cau, A., Moccia, D., Follesa, M.C., Alvito, A., Canese, S., Angiolillo, M., Cuccu, D., Bo, M., Cannas, R., 2017. Coral forests diversity in the outer shelf of the south Sardinian continental margin. Deep-Sea Res. Part I Oceanogr. Res. Pap. 122, 60-70. doi:10.1016/j.dsr.2017.01.016.

Cau, A., Bellodi, A., Moccia, D., Mulas, A., Pesci, P., Cannas, R., Pusceddu, A., Follesa, M.C., 2018. Dumping to the abyss: single-use marine litter invading bathyal plains of the Sardinian margin (Tyrrhenian Sea). Mar. Pollut. Bull. 135, 845-851. doi:10.1016/ j.marpolbul.2018.08.007.

Cau, A., Avio, C., Dessi, C., Moccia, D., Pusceddu, A., Regoli, F., Cannas, R., Follesa, M.C., 2020. Benthic crustacean digestion can modulate environmental fate of microplastics in the deep sea. Environ. Sci. Technol.. doi:10.1021/acs.est.9b07705.

Cerrano, C., Bianchelli, S., Di Camillo, C.G., Torsani, F., Pusceddu, A., 2015. Do colonies of Lytocarpia myriophyllum, L. 1758 (Cnidaria, Hydrozoa) affect the biochemical composition and the meiofaunal diversity of surrounding sediments? Chem. Ecol. 31, 1-21. doi:10.1080/02757540.2014.966699.

Cerrano, C., Bastari, A., Calcinai, B., Di Camillo, C., Pica, D., Puce, S., Valisano, L., Torsani, F., 2019. Temperate mesophotic ecosystems: gaps and perspectives of an emerging conservation challenge for the Mediterranean Sea. The European Zoological Journal 86, 370-388. doi:10.1080/24750263.2019.1677790.

Chimienti, G., 2020. Vulnerable forests of the pink sea fan Eunicella verrucosa in the Mediterranean sea. Diversity 12, 176. doi:10.3390/d12050176.

Chimienti, G., Bo, M., Taviani, M., Mastrototaro, F., 2019. Occurrence and biogeography of mediterranean cold-water corals. In: Orejas, C., Jiménez, C. (Eds.), Mediterranean Cold-Water Corals: Past, Present and Future. In: Coral Reefs of the World, 9. Springer, Cham. doi:10.1007/978-3-319-91608-8_19.

Chimienti, G., Di Nisio, A., Lanzolla, A.M.L., Andria, G., Tursi, A., Mastrototaro, F., 2019. Towards non-invasive methods to assess population structure and biomass in vulnerable sea pen fields. Sensors 19, 2255. doi:10.3390/s19102255.

Chimienti, G., De Padova, D., Mossa, M., Mastrototaro, F., 2020. A mesophotic black coral forest in the Adriatic Sea. Sci. Rep. 10 (1), 8504. doi:10.1038/s41598-020-65266-9.

Clark, M.R., Althaus, F., Schlacher, T.A., Williams, A., Bowden, D.A., Rowden, A.A., 2016. The impacts of deep-sea fisheries on benthic communities: a review. ICES (Int. Counc. Explor. Sea) J. Mar. Sci. 73, 51-69. doi:10.1093/icesjms/fsv123.

Corbera, G., Lo Iacono, C., Gràcia, E., Grinyó, J., Pierdomenico, M., Huvenne, V.A.I., Aguilar, R., Gili, J.M., 2019. Ecological characterisation of a mediterranean cold-water coral reef: cabliers coral mound province (alboran sea, western mediterranean). Prog. Oceanogr. 175, 245-262. doi:10.1016/j.pocean.2019.04.010.

D’Onghia, G., Capezzuto, F., Cardone, F., Carlucci, R., Carluccio, A., Chimienti, G., Corriero, G., Longo, C., Maiorano, P., Mastrototaro, F., Panetta, P., Rosso, A., Sanfilippo, R., Sion, L., Tursi, A., 2015. Macro- and megafauna recorded in the submarine Bari Canyon (southern Adriatic, Mediterranean Sea) using different tools. Mediterr. Mar. Sci. 16. doi:10.12681/mms.1082.

Danovaro, R., Company, J.B., Corinaldesi, C., D’Onghia, G., Galil, B., Gambi, C., Gooday, A., Lampadarius, N., Luna, G.M., Morigi, C., Olu, K., Polymenakou, P., Ramirez-Llodra, E., Sabbatini, A., Sardà, F., Sibuet, M., Tselepides, A., 2010. deep-sea biodiversity in the Mediterranean sea: the known, the unknown, and the unknowable. PloS One 5 (8), e11832. doi:10.1371/journal.pone.0011832.

Danovaro, R., Snelgrove, P.V.R., Tyler, P., 2014. Challenging the paradigms of deep-sea ecology. Trends Ecol. Evol. 1-11. doi:10.1016/j.tree.2014.06.002.

De Clippele, L.H., Huvenne, V.A.I., Orejas, C., Lundälv, T., Fox, A., Hennige, S.J., Roberts, J.M., 2018. The effect of local hydrodynamics on the spatial extent and morphology of cold-water coral habitats at Tisler Reef, Norway. Coral Reefs 37 (1), 253-266. doi:10.1007/s00338-017-1653-y.

De Clippele, L.H., Huvenne, V.A.I., Molodtsova, T.N., Murray Roberts, J., 2019. The diversity and ecological role of non-scleractinian corals (Antipatharia and Alcyonacea) on scleractinian cold-water coral mounds. Frontiers in Marine Science 6, 184. doi:10.3389/fmars.2019.00184.

De Leo, F.C., Smith, C.R., Rowden, A.A., Bowden, D.A., Clark, M.R., 2010. Submarine canyons: hotspots of benthic biomass and productivity in the deep sea. Proceedings of the Royal Society - Biological sciences 277, 2783-2792. doi:10.1098/rspb.2010.0462.
De Leo, F.C., Vetter, E.W., Smith, C.R., Rowden, A.A., McGranaghan, M., 2014. Spatial scale-dependent habitat heterogeneity influences submarine canyon macrofaunal abundance and diversity off the Main and Northwest Hawaiian Islands. Deep-Sea Res. Part II Top. Stud. Oceanogr. 104, 267-290. doi:10.1016/j.dsr2.2013.06.015.

Duffy, G.A., Lundsten, L., Kuhnz, L.A., Paull, C.K., 2014. A comparison of megafaunal communities in five submarine canyons off Southern California, USA. Deep-Sea Res. Part II Top. Stud. Oceanogr. 104, 259-266. doi:10.1016/j.dsr2.2013.06.002.

D’Onghia, G., Maiorano, P., Sion, L., Giove, A., Capezzuto, F., Carlucci, R., Tursi, A., 2010. Effects of deep-water coral banks on the abundance and size structure of the megafauna in the Mediterranean Sea. Deep-Sea Res. Part II Top. Stud. Oceanogr. 57, 397-411. doi:10.1016/j.dsr2.2009.08.022.

D’Onghia, G., Maiorano, P., Carlucci, R., Capezzuto, F., Carluccio, A., Tursi, A., Sion, L., 2012. Comparing deep-sea fish fauna between coral and non-coral "megahabitats" in the santa maria di Leuca cold-water coral province (Mediterranean sea). PloS One 7 (9). doi:10.1371/journal.pone.0044509.

D’Onghia, G., Calculli, C., Capezzuto, F., Carlucci, R., Carluccio, A., Grehan, A., Indennidate, A., Maiorano, P., Mastrototaro, F., Pollice, A., Russo, T., Savini, A., Sion, L., Tursi, A., 2017. Anthropogenic impact in the Santa Maria di Leuca cold-water coral province (Mediterranean Sea): observations and conservation straits. Deep-Sea Res. Part II Top. Stud. Oceanogr. 145, 87-101. doi:10.1016/j.dsr2.2016.02.012.

Enrichetti, F., Dominguez-Carrió, C., Toma, M., Bavestrello, G., Betti, F., Canese, S., Bo, M. 2019. Megabenthic communities of the Ligurian deep continental shelf and shelf break (NW Mediterranean Sea). PloS One 14 (10). doi:10.1371/journal.pone.0223949.

European Commission, 2006. Scientific, technical and economic committee for fisheries opinion on "sensitive and essential fish habitats in the Mediterranean Sea.

Fabri, M.C., Pedel, L., Beuck, L., Galgani, F., Hebbeln, D., Freiwald, A., 2014. Megafauna of vulnerable marine ecosystems in French mediterranean submarine canyons: spatial distribution and anthropogenic impacts. Deep-sea Research Part II: Topical Studies in Oceanography 104, 184-207. doi:10.1016/j.dsr2.2013.06.016.

Fabri, M.C., Bargain, A., Pairaud, I., Pedel, L., Taupier-Letage, I., 2017. Cold-water coral ecosystems in Cassidaigne Canyon: an assessment of their environmental living conditions. Deep-Sea Res. Part II Top. Stud. Oceanogr. 137, 436-453. doi:10.1016/ j.dsr2.2016.06.006

Fabri, M.C., Vinha, B., Allais, A.G., Bouhier, M.E., Dugornay, O., Gaillot, A., Arnaubec, A., 2019. Evaluating the ecological status of cold-water coral habitats using non-invasive methods: an example from Cassidaigne canyon, northwestern Mediterranean Sea. Prog. Oceanogr. 178 (April), 102172. doi:10.1016/j.pocean.2019.102172.

Fanelli, E., Bianchelli, S., Danovaro, R., 2018. Deep-sea megafauna of Mediterranean submarine canyons and open slopes: influence of spatial and bathymetric gradients. Prog. Oceanogr. 168, 23-34. doi:10.1016/j.pocean.2018.09.010.

FAO, 2009. In: Report of the Technical Consultation on International Guidelines for the Management of Dee-Sea Fisheries in the High Seas, 881. FAO, p. 98.

FAO, 2016. Vulnerable Marine Ecosystems: Processes and Practices in the High Seas, by Anthony Thompson, Jessica Sanders, Merete Tandstad, Fabio Carocci and Jessica Fuller. In: FAO Fisheries and Aquaculture Technical Paper No. 595. Rome, Italy.

Fernández-Arcaya, U., Ramirez-Llodra, E., Aguzzi, J., Allcock, A.L., Davies, J.S., Dissanayake, A., Harris, P., Howell, K., Huvenne, V.A.I., Macmillan-Lawler, M., Martín, J., Menot, L., Nizinski, M., Puig, P., Rowden, A.A., Sanchez, F., Van den Beld, I.M.J., 2017. Ecological role of submarine canyons and need for canyon conservation: a review. Frontiers of Marine Sciences 4, 5. doi:10.3389/fmars.2017.00005.

Galgani, F., Pham, C.K., Claro, F., Consoli, P., 2018. Marine animal forests as useful indicators of entanglement by marine litter. Mar. Pollut. Bull. 135 (July), 735-738. doi:10.1016/j.marpolbul.2018.08.004.

Garrabou, J., Harmelin, J.G., 2002. A 20-year study on life-history traits of a harvested long-lived temperate coral in the NW Mediterranean: insights into conservation and management needs. J. Anim. Ecol. 71, 966-978. doi:10.1046/ j.1365-2656.2002.00661.x.

Girard, F., Cruz, R., Glickman, O., Harpster, T., Fisher, C.R., 2019. In situ growth of deep-sea octocorals after the Deepwater Horizon oil spill. Elementa 7 (1). doi:10.1525/elementa.349.

Giusti, M., Bo, M., Angiolillo, M., Cannas, R., Cau, A., Follesa, M.C., Canese, S., 2017. Habitat preference of Viminella flagellum (Alcyonacea: ellisellidae) in relation to bathymetric variables in southeastern Sardinian waters. Continent. Shelf Res. 138, 41-50. doi:10.1016/j.csr.2017.03.004.

Giusti, M., Canese, S., Fourt, M., Bo, M., Innocenti, C., Goujard, A., Daniel, B., Angeletti, L., Taviani, M., Aquilina, L., Tunesi, L., 2019. Coral forests and derelict fishing gears in submarine canyon systems of the ligurian sea. Prog. Oceanogr. 178, 102186. doi:10.1016/j.pocean.2019.102186.

Gomes-Pereira, J.N., Carmo, V., Catarino, D., Jakobsen, J., Alvarez, H., Aguilar, R., Hart J., Giacomello, E., Menezes, G., Stefanni, S., Colaco, A., Morato, T., Santos, R.S. Tempera, F., Porteiro, F., 2017. Cold-water corals and large hydrozoans provide essential fish habitat for Lappanella fasciata and Benthocometes robustus. Deep-Sea Res. Part II Top. Stud. Oceanogr. 145, 33-48. doi:10.1016/j.dsr2.2017.09.015.

Gori, A., Rossi, S., Berganzo, E., Petrus, J.L., Dale, M.R.T., Gili, J.M., 2011. Spatial distribution patterns of the gorgonians Eunicella singularis, Paramuricea clavata, and Leptogorgia sarmentosa (cape of creus, northwestern Mediterranean sea). Mar. Biol. 158, 143-158. doi:10.1007/s00227-010-1548-8.

Gori, A., Reynaud, S., Orejas, C., Ferrier-Pagès, C., 2015. The influence of flow velocity and temperature on zooplankton capture rates by the cold-water coral 
Dendrophyllia cornigera. J. Exp. Mar. Biol. Ecol. 466, 92-97. doi:10.1016/ j.jembe.2015.02.004.

Gori, A., Bavestrello, G., Grinyó, J., Dominguez-Carrió, C., Ambroso, S., Bo, M., 2017. Animal forests in deep coastal bottoms and continental shelves of the Mediterranean sea. In: Rossi, S., Bramanti, L., Gori, A., Orejas, C. (Eds.), Marine Animal Forests. Springer, Cham, pp. 207-233. doi:10.1007/978-3-319-17001-5.

Grinyó, J., Gori, A., Greenacre, M., Requena, S., Canepa, A., Lo Iacono, C., Ambroso, S., Purroy, A., Gili, J.M., 2018. Megabenthic assemblages in the continental shelf edge and upper slope of the Menorca Channel, Western Mediterranean Sea. Prog. Oceanogr. 162, 40-51. doi:10.1016/j.pocean.2018.02.002.

Harris, P.T., Whiteway, T., 2011. Global distribution of large submarine canyons: geomorphic differences between active and passive continental margins. Mar. Geol. 285, 69-86. doi:10.1016/j.margeo.2011.05.008.

Henry, L.A., Navas, J.M., Hennige, S.J., Wicks, L.C., Vad, J., Murray Roberts, J., 2013. Cold-water coral reef habitats benefit recreationally valuable sharks. Biol. Conserv. 161, 67-70. doi:10.1016/j.biocon.2013.03.002.

Hinz, H., 2017. Impact of bottom fishing on animal forests: Science, conservation, and fisheries management. In: Rossi, S., Bramanti, L., Gori, A., Orejas, C. (Eds.), Marine Animal Forests: the Ecology of Benthic Biodiversity Hotspots, 1041-1059. Springer International Publishing. doi:10.1007/978-3-319-21012-4_37.

Kohler, K.E., Gill, S.M., 2006. Coral Point Count with Excel extensions (CPCe): a Visual Basic program for the determination of coral and substrate coverage using random point count methodology. Comput. Geosci. 32 (9), 1259-1269. doi:10.1016/ j.cageo.2005.11.009.

Larsson, A.I., van Oevelen, D., Purser, A., Thomsen, L., 2016. Tolerance to long-term exposure of suspended benthic sediments and drill cuttings in the cold-water coral Lophelia pertusa. Marine Pollution Bullettin 70, 176-188. doi:10.1016/ j.marpolbul.2013.02.033.

Lastras, G., Canals, M., Ballesteros, E., Gili, J.M., Sanchez-Vidal, A., 2016. Cold-water corals and anthropogenic impacts in La fonera submarine canyon head, northwestern Mediterranean sea. PloS One 11 (5), e0155729. doi:10.1371/journal.pone.0155729.

Levin, L., Sibuet, M., Gooday, A., 2010. The roles of habitat heterogeneity in generating and maintaining biodiversity on continental margins: an introduction. Mar. Ecol. 31, 1-5. doi:10.1111/j.1439-0485.2009.00358.x.

Mascle, G., Tricart, P., Torelli, L., Bouillin, J., Rolfo, F., Lapierre, H., Moniè, P., Depardon, S., Mascle, J., Peis, D., 2001. Evolution of the Sardinia channel (western mediterranean): new constraints from a diving survey on cornacya seamount off SE Sardinia. Mar. Geol. 179, 179-201. doi:10.1016/S0025-3227(01)00220-1.

McClain, C.R., Barry, J.P., 2010. Habitat heterogeneity, disturbance, and productivity work in concert to regulate biodiversity in deep submarine canyons. Ecology 91, 964-976. doi:10.1890/09-0087.1.

Moccia, D., Cau, A., Alvito, A., Canese, S., Cannas, R., Bo, M., Angiolillo, M., Follesa, M.C., 2019. New sites expanding the "Sardinian cold-water coral province" extension: a new potential cold-water coral network? Aquat. Conserv. Mar. Freshw. Ecosyst. 29, 153-160. doi:10.1002/aqc.2975.

Montagna, P., McCulloch, M., Taviani, M., Mazzoli, C., Vendrell, B., 2006. Phosphorus in cold-water corals as a proxy for seawater nutrient chemistry. Science 312, 1788-1791. doi:10.1126/science.1125781.

Okey, T.A., 2003. Macrobenthic colonist guilds and renegades in Monterey canyon (USA) drift algae: partitioning multidimensions. Ecol. Monogr. 73, 415-440. doi:10.1890/ 01-4088.

Orejas, C., Gori, A., Lo Iacono, C., Puig, P., Gili, J.M., Dale, M.R.T., 2009. Cold-water corals in the Cap de Creus canyon, northwestern Mediterranean: spatial distribution, density and anthropogenic impact. Marine Ecololgy Progress Seriers 397, 37-51. doi:10.3354/ meps08314.

Otero, M.M., Numa, C., Bo, M., 2016. Overview of the Conservation Status of Mediterranean Anthozoans. IUCN, Malaga, Spain, p. 73.

Pham, C.K., Ramirez-Llodra, E., Alt, C.H.S., Amaro, T., Bergmann, M., Canals, M., Company, J.B., Davies, J., Duineveld, G., Galgani, F., Howell, L.K., Huvenne, V.A.I., Isidro, E., Jones, D.O.B., Lastras, G., Morato, T., Gomes-Pereira, J.N., Purser, A., Stewart, H., Tojeira, I., Tubau, I., Rooij, X., Tyler, P.A., 2014. Marine litter distribution and density in european seas, from the shelves to deep basins. PloS One 9, e95839. doi:10.1371/journal.pone.0095839.

Pierdomenico, M., Cardone, F., Carluccio, A., Casalbore, D., Chiocci, F., Maiorano, P., D'Onghia, G., 2019. Megafauna distribution along active submarine canyons of the central Mediterranean: relationships with environmental variables. Prog. Oceanogr. 171, 49-69. doi:10.1016/j.pocean.2018.12.015.

Puig, P., Canals, M., Company, J.B., Martin, J., Amblas, D., Lastras, G., Palanques, A., Calafat, A.M., 2012. Ploughing the deep sea floor. Nature 489, 286-289. doi:10.1038/ nature11410.

Puig, P., Palanques, A., Martín, J., 2014. Contemporary sediment-transport processes in submarine canyons. Annual review of marine science 6, 53-77. doi:10.1146/ annurev-marine-010213-135037.

Pusceddu, A., Bianchelli, S., Canals, M., Sanchez-Vidal, A., Durrieu De Madron, X., Heussner, S., Lykousis, V., de Stigter, H., Trincardi, F., Danovaro, R., 2010.
Organic matter in sediments of canyons and open slopes of the Portuguese, Catalan, Southern Adriatic and Cretan Sea margins. Deep-Sea Res. Part I Oceanogr. Res. Pap. 57 (3), 441-457. doi:10.1016/j.dsr.2009.11.008.

QGIS Development Team QGIS user guidehttp://www.qgis.org2016

Ragnarsson, S.Á., Burgos, J.M., Kutti, T., van den Beld, I., Egilsdóttir, H., Arnaud-Haond, S., Grehan, A., 2016. The impact of anthropogenic activity on cold-water corals. In: Rossi, S., Bramanti, L., Gori, A., Orejas, C. (Eds.), Marine Animal Forests. Springer, pp. 1-35. doi:10.1007/978-3-319-17001-5_27-1.

Roberts, J.M., Cairns, S.D., 2014. Cold-water corals in a changing ocean. Current Opinion in Environmental Sustainability 7, 118-126. doi:10.1016/j.cosust.2014.01.004.

Rossi, S., 2013. The destruction of the "animal forests" in the oceans: towards an over-simplification of the benthic ecosystems. Ocean Coast Manag. 84, 77-85. doi:10.1016/j.ocecoaman.2013.07.004.

Rossi, S., Bramanti, L., Broglio, E., Gili, J.M., 2012. Trophic impact of long- lived species indicated by population dynamics in the short-lived hydrozoan Eudendrium racemosum. Mar. Ecol. Prog. Ser. 467, 97-111. doi:10.3354/meps09848.

Rossi, S., Bramanti, L., Gori, A., Orejas, C., 2017. An overview of the animal forests of the world. In: Rossi, S., Bramanti, L., Gori, A., Orejas, C. (Eds.), Marine Animal Forests. Springer, pp. 1-26. doi:10.1007/978-3-319-17001-5_1-1.

Rossi, S., Isla, E., Bosch-Belmar, M., Galli, G., Gori, A., Gristina, M., Ingrosso, G., Milisenda, G., Piraino, S., Rizzo, L., Schubert, N., Soares, M., Solidoro, C., Thurstan, R.H., Viladrich, N., Willis, T.J., Ziveri, P., 2019. Changes of energy fluxes in marine animal forests of the anthropocene: factors shaping the future seascape. ICES (Int. Counc. Explor. Sea) J. Mar. Sci. 76 (7), 2008-2019. doi:10.1093/icesjms/fsz147.

Sampaio, I., Braga-Henriques, A., Pham, C., Ocaña, O., de Matos, V., Morato, T., Porteiro, F.M., 2012. Cold-water corals landed by bottom longline fisheries in the Azores (north-eastern Atlantic). J. Mar. Biol. Assoc. U. K. 92, 1547-1555. doi:10.1017/ S0025315412000045.

Sardà, F., Calafat, A., Flexas, M.M., Tselepides, A., Canals, M., Espino, M., Tursi, A., 2004. An introduction to Mediterranean deep-sea biology. Sci. Mar. 68, 7-38. doi:10.3989/ scimar.2004.68s37.

Schlacher, T.A., Schlacher-Hoenlinger, M.A., Williams, A., Althaus, F., Hooper, J.N.A., Kloser, R., 2007. Richness and distribution of sponge megabenthos in continental margin canyons off southeastern Australia. Mar. Ecol. Prog. Ser. 340, 73-88. doi:10.3354/meps340073.

Schlacher, T.A., Williams, A., Althaus, F., Schlacher-Hoenlinger, M.A., 2010. High-resolution seabed imagery as a tool for biodiversity conservation planning on continental margins. Mar. Ecol. 31, 200-222. doi:10.1111/j.1439-0485.2009.00286.x.

Schlining, K., von Thun, S., Kuhnz, L., Schlining, B., Lundsten, L., Stout, N.J., Chaney, L., Connor, J., 2013. Debris in the deep: using a 22-year video annotation database to survey marine litter in Monterey Canyon, central California, USA. Deep Sea Res. Oceanogr. Res. Pap. 79, 96-105. doi:10.1016/j.dsr.2013.05.006.

Sulli, A., 2000. Structural framework and crustal characteristics of the Sardinia Channel Alpine transect in the central Mediterranean. Tectonophysics 324, 321-336. doi:10.1016/S0040-1951(00)00050-0.

Taviani, M., Angeletti, L., Canese, S., Cannas, R., Cardone, F., Cau, A., Cau, Al, Follesa, M.C., Marchese, F., Montagna, P., Tessarolo, C., 2017. The "Sardinian cold-water coral province" in the context of the mediterranean coral ecosystems. Deep Sea Res. Part II Top. Stud. Oceanogr. 145, 61-78. doi:10.1016/j.dsr2.2015.12.008.

UNGA, 2006. Resolution 61/105 Sustainable Fisheries, Including through the 1995 Agreement for the Implementation of the Provisions of the United Nations Convention on the Law of the Sea of 10 December 1982 Relating to the Conservation and Management of Straddling Fish Stocks and Highly Migratory Fish Stocks, and Related Instruments. UNGA A/RES/61/105.

Van Cauwenberghe, L., Vanreusel, A., Mees, J., Janssen, C.R., 2013. Microplastic pollution in deep-sea sediments. Environ. Pollut. 182, 495-499. doi:10.1016/ j.envpol.2013.08.013.

Vetter, E.W., 1994. Hotspots of benthic production. Nature 372, 47. doi:10.1038/ $372047 \mathrm{a} 0$

Weaver, P.E., Billett, D.M., Boetius, A., Danovaro, R., Freiwald, A., Sibuet, M., 2004 Hotspot ecosystem research on Europe's deep-ocean margins. Oceanography 7, 132-143. doi:10.5670/oceanog.2004.10.

Woodall, L.C., Sanchez-Vidal, A., Canals, M., Paterson, G.L.J., Coppock, R., Sleight, V., Calafat, A., Rogers, A.D., Narayanaswamy, B.E., Thompson, R.C., 2014. The deep sea is a major sink for microplastic debris. 1. Royal Society Open Science 4. doi:10.1098/ rsos. 140317.

Würtz, M., 2012. Submarine canyons and their role in the Mediterranean ecosystem. In: Würtz, M. (Ed.), Mediterranean Submarine Canyons: Ecology and Governance. Gland,Switzerland and Malaga, Spain, pp. 11-26. 